\title{
Using beryllium-7 to assess cross-tropopause transport in global models
}

\author{
Hongyu Liu ${ }^{1}$, David B. Considine ${ }^{2, a}$, Larry W. Horowitz ${ }^{3}$, James H. Crawford ${ }^{2}$, Jose M. Rodriguez ${ }^{4}$, \\ Susan E. Strahan ${ }^{4,5}$, Megan R. Damon ${ }^{4,6}$, Stephen D. Steenrod ${ }^{4,5}$, Xiaojing Xu ${ }^{7}$, Jules Kouatchou ${ }^{4,6}$, \\ Claire Carouge $^{8, b}$, and Robert M. Yantosca ${ }^{8}$ \\ ${ }^{1}$ National Institute of Aerospace, Hampton, VA, USA \\ ${ }^{2}$ NASA Langley Research Center, Hampton, VA, USA \\ ${ }^{3}$ NOAA Geophysical Fluid and Dynamics Laboratory, Princeton, NJ, USA \\ ${ }^{4}$ NASA Goddard Space Flight Center, Greenbelt, MD, USA \\ ${ }^{5}$ Universities Space Research Association, Columbia, MD, USA \\ ${ }^{6}$ Science Systems and Applications, Inc., Lanham, MD, USA \\ ${ }^{7}$ Science Systems and Applications, Inc., Hampton, VA, USA \\ ${ }^{8}$ John A. Paulson School of Engineering and Applied Sciences, Harvard University, Cambridge, MA, USA \\ ${ }^{a}$ now at: NASA Headquarters, Washington, D.C., USA \\ ${ }^{b}$ now at: ARC Centre of Excellence for Climate System Science, University of New South Wales, Sydney, Australia
}

Correspondence to: Hongyu Liu (hongyu.liu-1@ nasa.gov)

Received: 26 July 2015 - Published in Atmos. Chem. Phys. Discuss.: 25 September 2015

Revised: 16 March 2016 - Accepted: 23 March 2016 - Published: 14 April 2016

\begin{abstract}
We use the Global Modeling Initiative (GMI) modeling framework to assess the utility of cosmogenic beryllium-7 $\left({ }^{7} \mathrm{Be}\right)$, a natural aerosol tracer, for evaluating cross-tropopause transport in global models. The GMI chemical transport model (CTM) was used to simulate atmospheric ${ }^{7} \mathrm{Be}$ distributions using four different meteorological data sets (GEOS1-STRAT DAS, GISS II' GCM, fvGCM, and GEOS4-DAS), featuring significantly different stratosphere-troposphere exchange (STE) characteristics. The simulations were compared with the upper troposphere and/or lower stratosphere (UT/LS) ${ }^{7}$ Be climatology constructed from $\sim 25$ years of aircraft and balloon data, as well as climatological records of surface concentrations and deposition fluxes. Comparison of the fraction of surface air of stratospheric origin estimated from the ${ }^{7} \mathrm{Be}$ simulations with observationally derived estimates indicates excessive cross-tropopause transport at mid-latitudes in simulations using GEOS1-STRAT and at high latitudes using GISS II' meteorological data. These simulations also overestimate ${ }^{7} \mathrm{Be}$ deposition fluxes at mid-latitudes (GEOS1-STRAT) and at high latitudes (GISS II'), respectively. We show that excessive cross-tropopause transport of ${ }^{7} \mathrm{Be}$ corresponds to over-
\end{abstract}

estimated stratospheric contribution to tropospheric ozone. Our perspectives on STE in these meteorological fields based on ${ }^{7} \mathrm{Be}$ simulations are consistent with previous modeling studies of tropospheric ozone using the same meteorological fields. We conclude that the observational constraints for ${ }^{7} \mathrm{Be}$ and observed ${ }^{7} \mathrm{Be}$ total deposition fluxes can be used routinely as a first-order assessment of cross-tropopause transport in global models.

\section{Introduction}

Stratosphere-troposphere exchange (STE) of air masses and chemical species occurs at small, synoptic and global scales. It is typically associated with the occurrences of tropopause folding and cutoff cyclones and, more importantly, the global circulation of the atmosphere (Holton et al., 1995). While stratosphere-to-troposphere transport removes many chemical species from the stratosphere, it represents a significant source of ozone and other reactive species for the tropospheric chemical system (Stohl et al., 2003). Ozone is an important greenhouse gas, especially in the upper troposphere. 
It is a harmful pollutant near the surface where stratospheric ozone intrusions may make significant contributions (e.g., Lin et al., 2012, 2015; Langford et al., 2015). It is also the main precursor of hydroxyl radicals $(\mathrm{OH})$ and thus plays an essential role in the oxidizing capacity of the troposphere. In a warmer climate, the stratosphere may increase its contribution to tropospheric ozone levels due to a stronger residual circulation (Collins et al., 2003). Quantitative understanding and prediction of anthropogenic (vs. natural) perturbations to tropospheric ozone require the use of global 3-D models; correctly representing the STE flux in these models is therefore critical. However, current models show large (30\%) uncertainty in predicted STE fluxes of ozone (Stevenson et al., 2006). Here we use the Global Modeling Initiative (GMI) modeling framework (Douglass et al., 1999; Rotman et al., 2001) to assess the utility of the aerosol tracer beryllium$7\left({ }^{7} \mathrm{Be}\right)$ for evaluating cross-tropopause transport in global models.

Beryllium-7 has a half-life of 53.3 days and is produced by cosmic ray spallation reactions in the stratosphere and upper troposphere. After production, it attaches immediately to ubiquitous submicron aerosols in the ambient air. The fate of ${ }^{7} \mathrm{Be}$ then becomes that of those aerosols, which move with the air until scavenged by precipitation or deposited to the surface. ${ }^{7} \mathrm{Be}$ is a useful aerosol tracer for testing wet deposition processes in a global 3-D model and is often used in conjunction with the terrigenic ${ }^{210} \mathrm{~Pb}$ aerosol tracer, as wet deposition is its principal sink and its sources are relatively well known (e.g., Brost et al., 1991; Koch et al., 1996; Liu et al., 2001). On the other hand, because of its source at high altitudes and the large concentration vertical gradient, simulation of ${ }^{7} \mathrm{Be}$ tests the model's capability to describe stratosphere-to-troposphere transport and subsidence in the troposphere (e.g., Liu et al., 2001; Allen et al., 2003).

Beryllium-7 has long been recognized as a tracer of downward transport from the stratosphere to the troposphere (e.g., Husain et al., 1977; Viezee and Singh, 1980; Sanak et al., 1985; Dibb et al., 1992, 1994; Rehfeld and Heimann, 1995). Husain et al. (1977) reported that pulses of high ${ }^{7}$ Be concentrations were often associated with air masses of stratospheric origin, as indicated by large potential vorticity. Viezee and Singh (1980) showed that the ${ }^{7}$ Be concentrations over North America show strong positive correlations with the occurrence of tropopause folding events over several latitude belts. ${ }^{7} \mathrm{Be}$ has also been combined with other radionuclides (e.g., ${ }^{10} \mathrm{Be},{ }^{90} \mathrm{Sr}$ ) as an indicator of transport of stratospheric air to the troposphere (Raisbeck et al., 1981; Rehfeld and Heimann, 1995; Koch and Rind, 1998; Dibb et al., 1994; Jordan et al., 2003; Zanis et al., 2003; Heikkilä et al., 2008a, b). Dutkiewicz and Husain (1985, hereafter referred to as DH85) analyzed ${ }^{7} \mathrm{Be}$ and ${ }^{90} \mathrm{Sr}$ concentrations measured simultaneously in samples from NASA's Global Atmospheric Sampling Program (GASP) and showed that on an annual basis the stratosphere contributed $\sim 25 \%$ of the observed ${ }^{7} \mathrm{Be}$ concentration at the northern mid-latitude surface $(\sim 40 \%$ during late spring but only $10 \%$ during fall).

Beryllium-7 is also a useful tracer for vertical mixing and subsidence in the troposphere. Feely et al. (1989) examined the factors that contribute to seasonal variations in ${ }^{7} \mathrm{Be}$ concentrations in surface air. They found that the influences of variations both in the STE rate and in the tropospheric vertical mixing rate are evident in concentrations at most sites in mid-latitudes. Convective transport carries surface air upward and brings down the ${ }^{7} \mathrm{Be}$ at higher altitudes to the surface layer. This is also reflected by the ${ }^{7} \mathrm{Be} /{ }^{210} \mathrm{~Pb}$ ratio that peaks at the surface in summer when convective activity is at its maximum (Koch et al., 1996). On the other hand, despite the UT/LS source of ${ }^{7} \mathrm{Be}$ and the continental surface source of ${ }^{222} \mathrm{Rn}$ (precursor of ${ }^{210} \mathrm{~Pb}$ ), ${ }^{7} \mathrm{Be}$ concentrations have been reported to be positively correlated with ${ }^{210} \mathrm{~Pb}$ concentrations, reflecting mixing of subsiding middle- and upper-tropospheric air with continental lower-tropospheric air (Li et al., 2002; Dibb, 2007).

A number of observational studies have demonstrated the feasibility of using ${ }^{7} \mathrm{Be}$ to infer the contribution of ozonerich stratospheric air to ozone concentrations at ground level (e.g., Husain et al., 1977; Tsutsumi et al., 1998; Helmig et al., 2007) and in the free troposphere (e.g., Johnson and Viezee, 1981; Prospero et al., 1995; Graustein and Turekian, 1996; Kritz et al., 1991; Dibb et al., 2003). These studies are usually based on the correlations between concurrent measurements of ozone and ${ }^{7} \mathrm{Be}$ (as well as other tracers such as water vapor and calculated potential vorticity), with positive ${ }^{7} \mathrm{Be}$-ozone correlations indicating the presence of the upper-tropospheric or stratospheric air. For instance, Helmig et al. (2007) showed a year-round correlation of ozone with ${ }^{7} \mathrm{Be}$ at Summit, Greenland and concluded that surface-layer photochemical ozone production does not appear to have a noticeable influence on surface ozone levels. However, it is important to note that under some circumstances the observed positive correlations of surface ozone with ${ }^{7} \mathrm{Be}$ may simply reflect the common vertical trends of tropospheric ${ }^{7} \mathrm{Be}$ and ozone and does not necessarily indicate the influence of stratospheric air (Li et al., 2002). Recent global modeling studies showed the models' capability to reproduce the observed ${ }^{7} \mathrm{Be}$-ozone relationships, providing useful constraints on the stratospheric (vs. photochemical) contribution to tropospheric ozone in the model (Li et al., 2002; Allen et al., 2003; Liu et al., 2004).

Though correct representation of STE is essential for simulating ${ }^{7} \mathrm{Be}$, ozone and other trace species in the troposphere (e.g., Riese et al., 2012), large variations exist among models. Stevenson et al. (2006) reported the average STE flux of ozone from 26 models of $552 \pm 168 \mathrm{Tg}$ year $^{-1}$. Observationbased estimates of STE fluxes of ozone into the troposphere are typically in the range of 400-600 Tg year ${ }^{-1}$ (Murphy and Fahey, 1994). Some global models are able to produce STE fluxes of ozone in this range (e.g., Olsen et al., 2004; Hsu et al., 2005; Hsu and Prather, 2009; Lin et al., 2012; 
Young et al., 2013; Škerlak et al., 2014). For those models with too fast (or rarely, too slow) cross-tropopause transport of ozone, one way to overcome the difficulty is to use the Synoz (synthetic ozone) method (McLinden et al., 2000). The Synoz method involves constraining the global mean cross-tropopause ozone flux to match a prescribed value consistent with observations (e.g., Bey et al., 2001). But this method yields an unrealistic stratospheric ozone field and therefore does not allow for on-line calculations of total ozone columns and photolysis rates and/or heating rates (McLinden et al., 2000). By contrast, the other simple model for stratospheric ozone (linearized ozone or Linoz) developed by McLinden et al. (2000) enables these on-line calculations by linearizing the ozone tendency about the local ozone mixing ratio, temperature, and the overhead column ozone density. Linoz is computationally efficient and can be readily incorporated in climate models for long-term integrations. Nevertheless, using Linoz (or full stratospheric chemistry) in global CTMs or chemistry-climate models that focus on the troposphere requires a realistic model representation of net cross-tropopause total mass fluxes. In this context, ${ }^{7} \mathrm{Be}$ tracer simulations may provide a simple way of evaluating cross-tropopause transport in these models.

The intermodel differences in the estimated intensity and frequency of STE have been attributed to different meteorological fields used to drive the models as well as different transport algorithms and chemistry processes (Cristofanelli et al., 2003). The GMI modeling framework facilitates the reduction of uncertainties of this kind. It is a modular CTM with the ability to incorporate different inputs and components (e.g., meteorological fields, emission inventories, chemical and microphysical mechanisms, and numerical schemes) that represent the different approaches of current models. One of the distinct features of the GMI CTM is the ability to be driven by different meteorological data sets (e.g., Douglass et al., 1999; Considine et al., 2005; Liu et al., 2007) while maintaining the same algorithms for transport, deposition, emission, chemistry and other pertinent processes. This allows us to isolate the uncertainties in the model simulations due to differences in the meteorological data sets alone. The number of factors that may contribute to differences in the simulations is thus reduced, as we previously showed using the GMI simulated ${ }^{222} \mathrm{Rn}$ and ${ }^{210} \mathrm{~Pb}$ radionuclide tracers (Considine et al., 2005).

In this paper, we present simulations of atmospheric ${ }^{7} \mathrm{Be}$ distributions with the GMI CTM driven by four different meteorological data sets, including output from GEOS1STRAT, GISS II' GCM, fvGCM, and GEOS4-DAS, each featuring significantly different STE characteristics. The reader is referred to Table 1 for a list of acronyms of models and their driving meteorological data sets. We use here not only the meteorological fields that are well known to have reasonably good representations of STE (e.g., fvGCM), but also those with poor representations (e.g., GEOS1-STRAT). The variability in simulated STE allows us to examine and assess the utility of ${ }^{7} \mathrm{Be}$ for evaluating STE in these (and other) global meteorological fields. We will illustrate the consequences of incorrect STE in terms of the simulation of tropospheric ${ }^{7} \mathrm{Be}$ and show that ${ }^{7} \mathrm{Be}$ concentrations and deposition fluxes may be used routinely as a first-order assessment for cross-tropopause transport in global models. We will discuss how the constraints on STE from ${ }^{7} \mathrm{Be}$ are consistent with previous modeling studies of tropospheric ozone using the same meteorological fields.

The remainder of this paper is organized as follows. Section 2 gives a brief description of the GMI model, ${ }^{7} \mathrm{Be}$ source and cross-tropopause flux, and ${ }^{7} \mathrm{Be}$ and ozone observational data sets used for evaluating the model. Section 3 evaluates model results with UT/LS and surface ${ }^{7} \mathrm{Be}$ data. Section 4 assesses cross-tropopause transport of ${ }^{7} \mathrm{Be}$ in different meteorological fields. Section 5 compares the results with previous modeling studies. Section 6 discusses the implications for the impact of STE on tropospheric ozone, followed by the summary and conclusions in Sect. 7.

\section{Model and data}

\subsection{GMI CTM}

The GMI (http://gmi.gsfc.nasa.gov) CTM is a global 3-D composition model that includes a full treatment of both stratospheric and tropospheric photochemical and physical processes. It uses a 114-species chemical mechanism that combines the stratospheric mechanism of Douglass et al. (2004) with the tropospheric mechanism of Bey et al. (2001). The chemical mechanism includes both stratospheric and tropospheric heterogeneous reactions. Tropospheric aerosol (sulfate, dust, sea salt, organic carbon, and black carbon) fields are taken from the Goddard Chemistry, Aerosol, Radiation and Transport model (GOCART). Details of the model are described in Duncan et al. (2007, 2008), Strahan et al. (2007), and Considine et al. (2008). There is also a tropospheric version of the model that includes only tropospheric chemistry processes and uses the Synoz (synthetic ozone) scheme (McLinden et al., 2000) to ensure a given value for the total flux of ozone into the troposphere. The latter adopts a cross-tropopause ozone flux of about 530$590 \mathrm{Tg} \mathrm{year}^{-1}$ (Stevenson et al., 2006). In this study, we simulate ${ }^{7} \mathrm{Be}$ using the GMI CTM without chemistry, similar to the Considine et al. (2005) study that simulated the radionuclides ${ }^{222} \mathrm{Rn}$ and ${ }^{210} \mathrm{~Pb}$. We use both the full-chemistry CTM and the tropospheric version of the model for ozone simulations.

The simulations presented in this paper differ only in the meteorological data used to drive the model. The four input meteorological data sets are from (1) the Goddard Space Flight Center Data Assimilation Office (now Global Modeling and Assimilation Office or GMAO) GEOS1STRAT data assimilation system (GEOS1-STRAT DAS, 
Table 1. Acronyms of the model and driving meteorological data sets.

\begin{tabular}{ll}
\hline Model/Data Set & \multicolumn{1}{c}{ Acronym } \\
\hline GMI CTM & $\begin{array}{c}\text { Global Modeling Initiative Chemical Transport Model } \\
\text { GEOS1-STRAT DAS } \\
\text { Goddard Earth Observing System Data Assimilation System - version 1 } \\
\text { in support of the Stratospheric Tracers of Atmospheric Transport mission } \\
\text { GISS II' GCM }\end{array}$ \\
$\begin{array}{l}\text { Goddard Institute for Space Studies General Circulation Model - version II' } \\
\text { fvGCM }\end{array}$ & Global Modeling and Assimilation Office (GMAO) finite-volume GCM \\
GEOS4-DAS & GEOS Data Assimilation System - version 4 \\
\hline
\end{tabular}

March 1997-February 1998), (2) GISS II' GCM (Rind and Lerner, 1996), (3) the GMAO finite-volume GCM (fvGCM), and (4) GEOS4-DAS (February 2004-January 2005). The GISS II' GCM data set is used for ${ }^{7} \mathrm{Be}$ simulations only. The two GCM data sets are intended to represent not any particular year but the contemporary climatological state of the Earth's atmosphere. Note that these data sets do not reflect the state of the art, especially the first two. However, the choices are purposely made in order to see how a meteorological input with a poor representation of cross-tropopause transport affects the simulated tropospheric ${ }^{7} \mathrm{Be}$. Vertical levels, top pressure, near-tropopause resolution, and bottom layer depth for each data set are listed in Table 2. The simulations presented here use a degraded horizontal resolution $\left(4^{\circ} \times 5^{\circ}\right)$ for computational expediency. Degraded horizontal resolution slightly increases cross-tropopause transport (Liu et al., 2001). Nevertheless, our objective is to assess crosstropopause transport in meteorological data sets at the resolution used to drive the model, not necessarily at the original or finer resolution.

The model uses the flux form semi-Lagrangian advection scheme (FFSL) of Lin and Rood (1996) and a convective transport algorithm adapted from the CONVTRAN routine in the NCAR CCM3 physics package. The wet deposition scheme is that of Liu et al. (2001) and includes scavenging in wet convective updrafts, and first-order rainout and washout from both convective anvils and large-scale precipitation. The gravitational settling effect of cloud ice particles included in Liu et al. (2001) is not considered here. Dry deposition of ${ }^{7} \mathrm{Be}$ aerosols is computed using the resistance-inseries approach. The model tracks the bulk ${ }^{7} \mathrm{Be}$ aerosol mass. For ${ }^{7} \mathrm{Be}$ simulations, each simulation was run for 6 years, recycling the meteorological data for each year of the simulation; we use the sixth year output for analysis. For ozone simulations, the model was spun up for 10 years to remove the effect of initial conditions. Interannual variability in STE of ${ }^{7} \mathrm{Be}$ is not shown in this paper. However, model simulations driven by multi-year outputs from fvGCM (1994-1998) indicate that such interannual variability is much smaller than the differences due to using different meteorological data sets and does not affect the conclusions of this study.

The GMI CTM has been used previously to study the sensitivities of model simulations to different sets of meteoro- logical input. Douglass et al. (1999) used chemical tracers in the GMI framework to assess three meteorological data sets, i.e., the NCAR Community Climate Model (CCM2), GEOS1-STRAT, and GISS II' GCM. They concluded that overall, CCM2 provides the best representation of the stratosphere. Considine et al. (2005) used the GMI model to simulate the radionuclides ${ }^{222} \mathrm{Rn}$ and ${ }^{210} \mathrm{~Pb}$ using three different sets of meteorological inputs (GEOS1-STRAT, GISS II', and CCM3) to characterize the variability occurring in their simulations. Overall no simulation was found to be superior to the others when compared with the climatological observations of these radionuclides. The role played by convective transport and scavenging was found to differ substantially among the three meteorological data sets. Liu et al. (2007) analyzed and quantified the differences and uncertainties in GMI aerosol simulations solely due to different meteorological fields (GEOS1-STRAT, GISS II' GCM, and fvGCM). They suggested that the differences in the precipitation, convective mass flux, and horizontal advection from the three meteorological data sets explain much of the large discrepancies in the model-calculated aerosol concentrations.

\subsection{Comparison of cloud and precipitation fields between meteorological data sets}

Clouds and precipitation play a critical role in the transport and scavenging of ${ }^{7} \mathrm{Be}$ aerosols and thus in determining the lifetime, burden, and distribution of ${ }^{7} \mathrm{Be}$ in the troposphere. Figures 1 and 2 compare the annual surface total precipitation and convective mass fluxes in the GEOS1STRAT, GISS II' GCM, fvGCM and GEOS4-DAS meteorological data sets, respectively, following Liu et al. (2007). Also shown in Fig. 1 is the satellite climatology of surface total precipitation (1979-2009) from the Global Precipitation Climatology Project (GPCP) (Adler, 2003). The global mean precipitation rates are 1.9, 2.2, 2.6, 2.3 and $2.2 \mathrm{~mm} \mathrm{day}^{-1}$ for GEOS1-STRAT, GISS II' GCM, fvGCM, GEOS4-DAS and GPCP, respectively, with lightest precipitation in GEOS1-STRAT and heaviest in fvGCM. Compared to GPCP, GEOS1-STRAT and GEOS4-DAS significantly underestimate the precipitation in the mid-latitude storm track regions, while GISS $\mathrm{II}^{\prime}$ GCM, fvGCM and GEOS4-DAS largely overestimate the observations in the tropics or subtropics. GISS II' GCM also underestimates the precipitation 
Table 2. Characteristics of meteorological data sets used to drive the GMI CTM.

\begin{tabular}{lrrlrrrr}
\hline Data Set & $\begin{array}{r}\text { Number } \\
\text { of levels }\end{array}$ & $\begin{array}{r}\text { Top pressure } \\
(\mathrm{hPa})\end{array}$ & $\begin{array}{l}\text { Vertical } \\
\text { coordinate }\end{array}$ & $\begin{array}{r}\text { Interface pressure } \\
(\mathrm{hPa})^{\mathrm{a}}\end{array}$ & $\begin{array}{r}\text { Near-tropopause } \\
\text { resolution }(\mathrm{km})\end{array}$ & $\begin{array}{r}\text { Bottom layer } \\
\text { depth }(\mathrm{hPa}, \mathrm{m})\end{array}$ & $\begin{array}{r}\text { Update } \\
\text { period }(\mathrm{h})\end{array}$ \\
\hline GEOS1-STRAT & 46 & 0.1 & $\sigma$ & $\mathrm{n} / \mathrm{a}$ & $\sim 1.0$ & $\sim 12.13 \mathrm{hPa}, \sim 100 \mathrm{~m}$ \\
GISS II' & 23 & 0.002 & $\sigma-P$ & 150 & $\sim 1.8-2.5$ & $\sim 24.46 \mathrm{hPa}, \sim 200 \mathrm{~m}$ \\
fvGCM & $42\left(55^{\mathrm{b}}\right)$ & $0.9\left(0.01^{\mathrm{b}}\right)$ & $\sigma-P$ & 200 & $\sim 1.0$ & $\sim 14.89 \mathrm{hPa}, \sim 130 \mathrm{~m}$ \\
GEOS4 & $42\left(55^{\mathrm{b}}\right)$ & $0.9\left(0.01^{\mathrm{b}}\right)$ & $\sigma-P$ & 200 & $\sim 1.0$ & $\sim 14.89 \mathrm{hPa}, \sim 130 \mathrm{~m}$ \\
\hline
\end{tabular}

a The hybrid vertical coordinate consists of sigma $(\sigma)$ levels below the interface pressure and constant pressure $(P)$ levels above.

$\mathrm{b}$ The total number of vertical levels and top level pressure in the original meteorological data set.
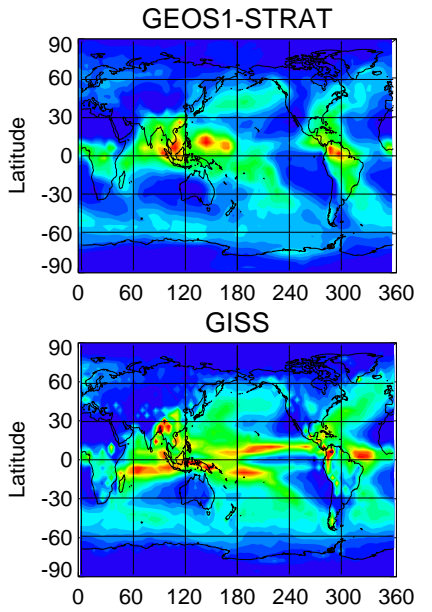

GPCP

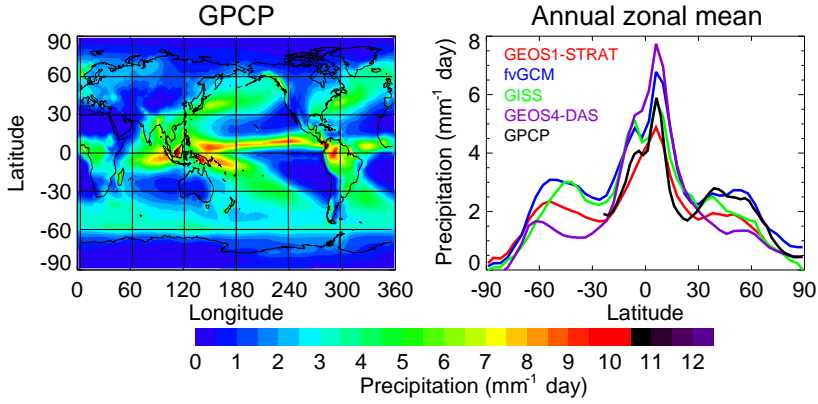

Figure 1. Annual mean total precipitation $\left(\mathrm{mm} \mathrm{day}^{-1}\right)$ at the surface in the GEOS1-STRAT, GISS II', fvGCM, and GEOS4-DAS meteorological data sets and in the observational data set from the Global Precipitation Climatology Project (GPCP, 1979-2009). Also shown is the annual zonal mean precipitation (bottom right panel).

south of $50^{\circ} \mathrm{S}$ and north of $40^{\circ} \mathrm{N}$. There are significant differences in the convective mass fluxes among the four meteorological data sets (Fig. 2). Consistent with the precipitation, GEOS1-STRAT shows the weakest convection except in the tropical middle and upper troposphere, whereas fvGCM features the strongest convection in the boundary layer at 30 $60^{\circ} \mathrm{S}$. The effects of the above differences in convection and precipitation between meteorological data sets on the results of this study will be examined through model sensitivity experiments.
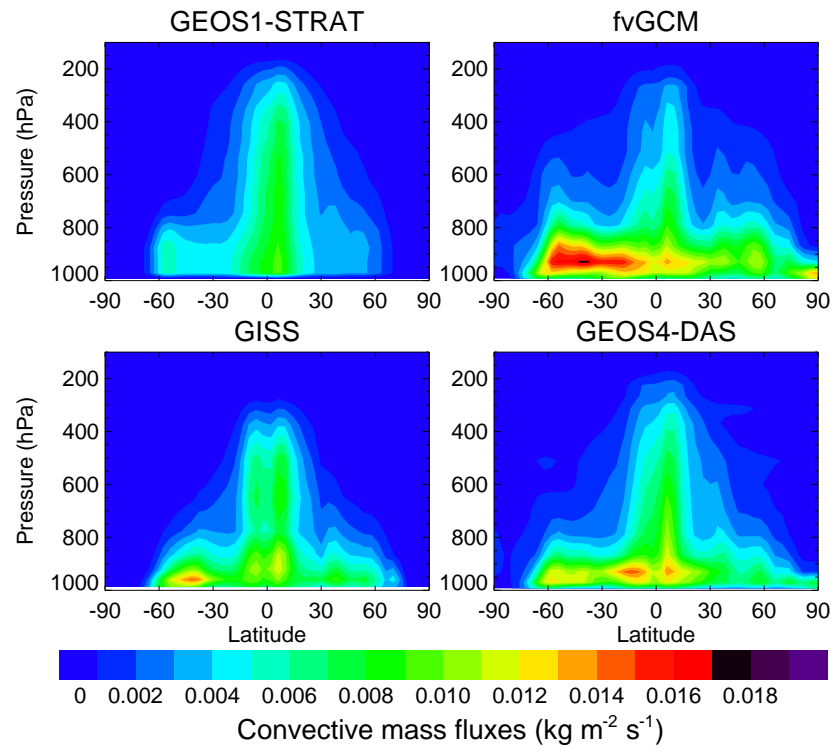

Figure 2. Annual zonal mean convective mass fluxes $\left(\mathrm{kg} \mathrm{m}^{-2} \mathrm{~s}^{-1}\right)$ in the GEOS1-STRAT, GISS II' GCM, fvGCM, and GEOS4-DAS meteorological data sets.

\section{$2.3 \quad{ }^{7}$ Be source}

There is a large discrepancy in the published estimates of ${ }^{7} \mathrm{Be}$ production rates (Lal and Peters, 1967, referred to as LP67 hereafter; O'Brien et al., 1991; Masarik and Reedy, 1995; Masarik and Beer, 1999; Usoskin and Kovaltsov, 2008). Global mean column production rates over an average solar cycle range from 0.035 atoms $\mathrm{cm}^{-2} \mathrm{~s}^{-1}$ (Masarik and Beer, 1999), 0.063 atoms $\mathrm{cm}^{-2} \mathrm{~s}^{-1}$ (O'Brien et al., 1991), to 0.081 atoms $\mathrm{cm}^{-2} \mathrm{~s}^{-1}$ (LP67). The Masarik and Beer (1999) production function is smaller than other estimates by a factor of 2 or more. It may have underestimated the rate of ${ }^{7} \mathrm{Be}$ production and slightly overestimated changes in the production rate due to variations in geomagnetic and solar magnetic field strength (Koch et al., 2006; Field et al., 2006). We use in the model the LP67 source for 1958 (solar maximum year) since it leads to the best simulation of aircraft ${ }^{7} \mathrm{Be}$ observations in the stratosphere where ${ }^{7} \mathrm{Be}$ concentrations are mainly determined by a balance between production and radioactive decay (Koch et al., 1996; Liu et al., 2001). Koch 
et al. (1996) previously found that the O'Brien et al. (1991) source yields model ${ }^{7} \mathrm{Be}$ concentrations near the surface and in the stratosphere that are much lower than observed. The rates of ${ }^{7} \mathrm{Be}$ production reported more recently by Usoskin and Kovaltsov (2008) broadly agree with those of LP67 with slightly (about $25 \%$ ) lower global production rate and will be tested in a separate model study. The LP67 source is represented as a function of latitude and altitude (pressure) and does not vary with season (see Fig. 1 of Koch et al., 1996). About $2 / 3$ of atmospheric ${ }^{7} \mathrm{Be}$ is generated in the stratosphere and $1 / 3$ in the troposphere. The ${ }^{7} \mathrm{Be}$ production rate correlates inversely with solar activity. At higher solar activity, cosmic rays are deflected away from the solar system and the ${ }^{7} \mathrm{Be}$ production rate is thus lower.

\subsection{Constraint on stratospheric contribution to ${ }^{7} \mathrm{Be}$ at the surface}

Cross-tropopause transport is important for simulating ${ }^{7} \mathrm{Be}$ in the troposphere. A useful constraint on the stratospheric contribution to tropospheric ${ }^{7} \mathrm{Be}$ is $\mathrm{DH} 85$ 's analysis of the observed ${ }^{7} \mathrm{Be} /{ }^{90} \mathrm{Sr}$ ratio in the stratosphere and ${ }^{90} \mathrm{Sr}$ concentrations at the surface. The presence of fissiogenic ${ }^{90} \mathrm{Sr}$ in the troposphere is due entirely to downward transport from the stratosphere, except for a few weeks right after a nuclear detonation. Both ${ }^{7} \mathrm{Be}$ and ${ }^{90} \mathrm{Sr}$ are associated with submicron particles; their fates during transport from the stratosphere are expected to be similar (no differential removal is expected). The stratospheric ${ }^{7} \mathrm{Be}$ component in surface air can therefore be determined as the product of the stratospheric ${ }^{7} \mathrm{Be} /{ }^{90} \mathrm{Sr}$ ratio and the surface ${ }^{90} \mathrm{Sr}$ concentration (DH85). By this procedure, DH85 showed that annually $23-27 \%$ (or about $25 \%$ on average) of the ${ }^{7} \mathrm{Be}$ in surface air at northern mid-latitudes is of stratospheric origin. To use this constraint, we diagnose stratospheric contribution to ${ }^{7} \mathrm{Be}$ concentrations in the troposphere by transporting separately in the model the ${ }^{7} \mathrm{Be}$ produced in the stratosphere, as we previously applied in GEOS-Chem with GEOS1-DAS meteorological data (Liu et al., 2001). Since wet deposition removes both the stratospheric and tropospheric components of ${ }^{7} \mathrm{Be}$ at the same rate within each model gridbox, the diagnosed stratospheric fraction of ${ }^{7} \mathrm{Be}$ concentrations in the troposphere does not significantly depend on the rate of wet removal.

In the stratosphere, the production of ${ }^{7} \mathrm{Be}$ (source) is balanced by radioactive decay and net STE fluxes of ${ }^{7} \mathrm{Be}$ into the troposphere (sinks), i.e.,

source $\left({ }^{7} \mathrm{Be}\right)=\operatorname{decay}\left({ }^{7} \mathrm{Be}\right)+\operatorname{STE}\left({ }^{7} \mathrm{Be}\right)$.

Since the timescale for downward transport from the stratosphere to troposphere ( $\sim 1-2$ years) is much longer than that for radioactive decay (half-life 53.3 days), the radioactive decay term is much larger than the STE flux term. Nevertheless, the STE term would become more important for a model atmosphere where STE is too fast. For the simulation of tropospheric (not stratospheric) ${ }^{7} \mathrm{Be}$, the stratospheric influx to the troposphere may be adjusted by artificially scaling down (in the case of excessive STE) or up (in the case of too slow STE) the stratospheric ${ }^{7} \mathrm{Be}$ source. The extent to which ${ }^{7} \mathrm{Be}$ crosstropopause transport is excessive or too slow in the model can be indicated by a scaling factor $A$, which is defined as the ratio of model to observed STE fluxes of ${ }^{7} \mathrm{Be}$. We derive the scaling factor $A$ as follows.

According to the DH85 constraint, we have for the observations

$\left[{ }^{7} \mathrm{Be}\right]_{T, G} /\left[{ }^{7} \mathrm{Be}\right]_{S, G}=(1-0.25) / 0.25=3$,

where the left-hand side denotes the ratio of the tropospheric $\left(\left[{ }^{7} \mathrm{Be}\right]_{T, G}\right)$ to stratospheric $\left(\left[{ }^{7} \mathrm{Be}\right]_{S, G}\right)$ component of annual mean ${ }^{7} \mathrm{Be}$ concentrations in ground air at $\mathrm{NH}$ mid-latitudes. On the other hand, we have for a global model

$\left[{ }^{7} \mathrm{Be}\right]_{T, G^{\prime}} /\left[{ }^{7} \mathrm{Be}\right]_{S, G^{\prime}}=(1-F) / F$,

where $\left[{ }^{7} \mathrm{Be}\right]_{T, G^{\prime}}$ and $\left[{ }^{7} \mathrm{Be}\right]_{S, G^{\prime}}$ are the model tropospheric and stratospheric components of annual mean ${ }^{7} \mathrm{Be}$ concentrations in surface air at $\mathrm{NH}$ mid-latitudes, respectively, and $F$ is the corresponding fraction of surface air of stratospheric origin in the model. If the model reasonably represents the vertical transport and wet scavenging processes in the troposphere, we have

$\left[{ }^{7} \mathrm{Be}\right]_{T, G^{\prime}}=\left[{ }^{7} \mathrm{Be}\right]_{T, G}$.

Combining Eqs. (2)-(4), we obtain the scaling factor

$A \approx\left[{ }^{7} \mathrm{Be}\right]_{S, G^{\prime}} /\left[{ }^{7} \mathrm{Be}\right]_{S, G} \approx 3 F /(1-F)$.

We will discuss the sensitivity of $F$ and $A$ to the assumptions with respect to convective transport and scavenging processes in Sect. 4. The validity of Eq. (5) will also be evaluated with actual model calculations in that section. Unless otherwise specified, ${ }^{7} \mathrm{Be}$ cross-tropopause fluxes in the model calculations presented in this paper are not adjusted. However, we will use the scaling factor $A$ as one of the metrics for comparing the STE characteristics of different meteorological data sets.

\section{$2.5 \quad{ }^{7}$ Be and ozone observational data}

2.5.1 ${ }^{7} \mathrm{Be}$

We estimate an average solar year value simply by averaging the long-term records of ${ }^{7} \mathrm{Be}$ observations multiplied by 0.72 to correct to the 1958 solar maximum source (Koch et al., 1996). The ${ }^{7} \mathrm{Be}$ deposition flux observations are from the compilation of Koch et al. (1996) and there are about 25 northern mid-latitude sites with available long-term ${ }^{7} \mathrm{Be}$ observations. The ${ }^{7} \mathrm{Be}$ surface concentration observations are from the data archive of the US Department of Energy (DOE) Environmental Measurements Laboratory (EML, now part of the Department of Homeland Security) Surface Air Sampling Program (SASP) which began in the 1980s. We also 
use the long-term climatological data of ${ }^{7} \mathrm{Be}$ concentrations in the UT/LS constructed from $\sim 25$ years of aircraft and balloon observations. Between the late 1950s and the early 1980s, EML collected tropospheric and stratospheric aircraft and balloon measurements of numerous radionuclides as part of the DOE High Altitude Sampling Program (HASP). The data were compiled into a database in 1997 by R. Leifer and N. Chan of EML (Leifer and Chan, 1997), called RAdioNuclide DAtaBase (RANDAB). The reader is referred to Considine et al. (2005) for a brief description of the RANDAB database. This database is available at the Oak Ridge National laboratory's Carbon Dioxide Information Analysis Center (http://cdiac.esd.ornl.gov/ndps/db1019.html).

\subsubsection{Ozone}

We use tropospheric ozone column (TOC) determined with the tropospheric ozone residual method by subtracting measurements of MLS stratospheric column ozone (SCO) from OMI total column ozone (Ziemke et al., 2006; http:// acdb-ext.gsfc.nasa.gov/Data_services/cloud_slice) or using the TOMS and Solar Backscatter Ultraviolet (SBUV) combination (Fishman et al., 2003; http://science.larc.nasa.gov/ TOR). The OMI/MLS TOCs are from October 2004 to July 2008, and the TOMS/SBUV TOCs are from 1979 to 2005. We use climatological monthly average ozone profiles from 23 ozonesonde stations as constructed by Considine et al. (2008), based on Logan (1999) and Thompson et al. (2003). The ozonesonde data record is from 1985-2000 for extratropical stations, and from all available data prior to 2005 for tropical stations. The number of sondes at each station is adequate for defining monthly means used to evaluate the accuracy of the model results (Considine et al., 2008). Surface ozone data are taken from Logan (1999).

\section{Model evaluation with UT/LS and surface ${ }^{7}$ Be data}

In this section, we present model results of ${ }^{7} \mathrm{Be}$ simulations driven by four meteorological archives and evaluate them against long-term measurements at the surface and in the UT/LS. Figure 3 shows the annual zonal mean concentrations (in units of millibequerel per standard cubic meter or $\mathrm{mBq} \mathrm{SCM}^{-1}$ ) of ${ }^{7} \mathrm{Be}$ in the four radionuclide simulations using GMI CTM. All four simulations overall show a similar pattern of tropospheric distribution. The highest concentrations are seen in the dry subsiding subtropics. Lowest ${ }^{7} \mathrm{Be}$ concentrations in surface air are found in the Southern Hemisphere mid-latitudes owing to scavenging by frequent largescale precipitation (Fig. 1). Low ${ }^{7} \mathrm{Be}$ concentrations are also associated with ITCZ, which is characterized by strong convergence and convective precipitation. It appears, however, that among all four simulations the GEOS1-STRAT simulation gives the highest concentrations in the subtropics and the GISS simulation shows the highest concentrations in the

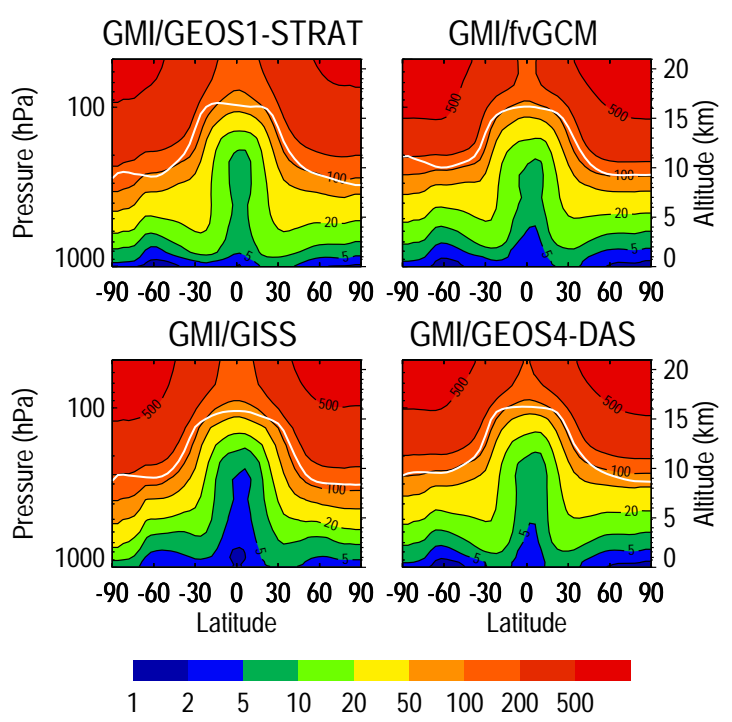

Figure 3. Annual zonal mean mixing ratios $\left(\mathrm{mBq} \mathrm{SCM}^{-1}\right)$ of ${ }^{7} \mathrm{Be}$ as a function of latitude and pressure (altitude), as simulated by the standard GMI CTM. The white lines indicate the annual average thermal tropopause height.

high latitudes. This is partly attributed to the differences in the latitudinal distribution of total precipitations in these meteorological archives (Fig. 1).

Figure 4 compares four ${ }^{7} \mathrm{Be}$ simulations in the upper troposphere and/or lower stratosphere (UT/LS) with climatological distributions constructed from the ${ }^{7} \mathrm{Be}$ data contained in the RANDAB database, following Considine et al. (2005) who previously made a similar comparison for ${ }^{210} \mathrm{~Pb}$. Model output are sampled at the months, longitudes, latitudes, and altitudes of the ${ }^{7} \mathrm{Be}$ observations. Figure $4 \mathrm{a}$ compares the meridional distribution of ${ }^{7} \mathrm{Be}$ measurements made in the $12-16 \mathrm{~km}$ altitude range with the four GMI simulations. Figure $4 \mathrm{~b}$ shows the same comparison, but for the $16-20 \mathrm{~km}$ altitude range. The $12-16 \mathrm{~km}$ (about $200-100 \mathrm{hPa}$ ) range lies within the upper troposphere in the tropics and the lower stratosphere at mid to high latitudes. The $16-20 \mathrm{~km}$ (about $100-50 \mathrm{hPa}$ ) range lies within the stratosphere at all latitudes.

At $12-16 \mathrm{~km}$ (Fig. 4a), the observations indicate comparatively low tropical upper tropospheric values of $\sim 35 \mathrm{mBq} \mathrm{SCM}^{-1}$, with increasing trends toward high latitudes. The distribution is nearly symmetric about the equator, with more observations available in $\mathrm{NH}$ high latitudes. This latitudinal distribution of ${ }^{7} \mathrm{Be}$ concentrations reflects a larger production of ${ }^{7} \mathrm{Be}$ in the lower stratosphere at high latitudes and precipitation scavenging associated with deep convection in the tropics. All four simulations capture the observations at $12-16 \mathrm{~km}$ reasonably well. The differences between the four simulated ${ }^{7} \mathrm{Be}$ concentrations are comparable or smaller than the error limits. 

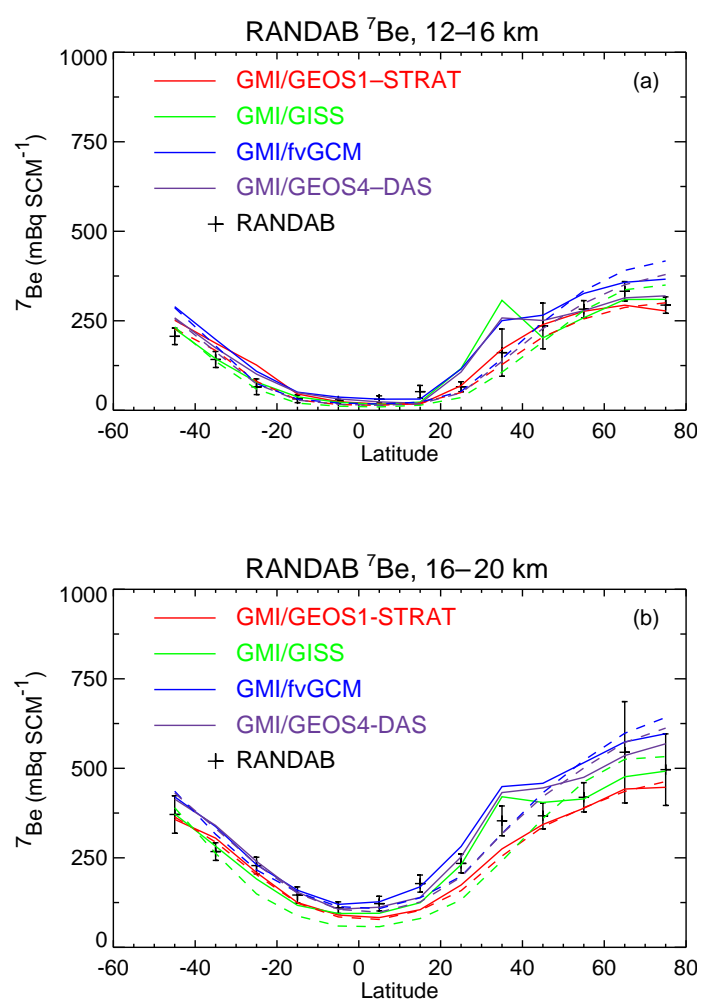

Figure 4. Observed and simulated latitudinal distributions of ${ }^{7} \mathrm{Be}$ in the (a) $12-16 \mathrm{~km}$ and (b) $16-20 \mathrm{~km}$ regions. Observed data from the EML RANDAB database are averaged into $10^{\circ}$ bins, following Considine et al. (2005). Error bars represent \pm 2 times the standard error of the averages. Model results are sampled at observation locations on a monthly basis. Also shown as dashed lines are model zonal mean ${ }^{7} \mathrm{Be}$ concentrations to show the global representativeness of the averages constructed from sampling the simulations at the observation locations.

At $16-20 \mathrm{~km}$ (Fig. 4b), the observations show a tropical minimum of $\sim 150 \mathrm{mBq} \mathrm{SCM}^{-1}$, with increasing concentrations toward high latitudes in both hemispheres. In the tropics and the $\mathrm{SH}$, the four ${ }^{7} \mathrm{Be}$ simulations indicate small differences. In the $\mathrm{NH}$, the four ${ }^{7} \mathrm{Be}$ simulations reveal large differences and bracket the observations. In particular, the GMI/GEOS1-STRAT simulation gives the lowest ${ }^{7} \mathrm{Be}$ concentrations among the four simulations and is lower than the observations. This appears to be due to excessive cross-tropopause transport in GEOS1-STRAT, as further discussed below. On the other hand, as we will also discuss later, the fvGCM and GEOS4-DAS meteorological fields have reasonable cross-tropopause transport. In the latter case, stratospheric ${ }^{7} \mathrm{Be}$ concentrations are primarily determined by a balance between production and radioactive decay in the stratosphere. Therefore the slightly overestimated ${ }^{7} \mathrm{Be}$ at $16-20 \mathrm{~km}$ suggests a slightly overestimated global production rate of ${ }^{7} \mathrm{Be}$ in the LP67 source. The Usoskin and Kovaltsov (2008) source, which is about $25 \%$ lower than the
LP67 source, would probably yield better agreements with the ${ }^{7} \mathrm{Be}$ observations in the lower stratosphere.

Figure 5a compares the simulated and observed annual average concentrations of ${ }^{7} \mathrm{Be}$ near the surface as a function of latitude. Observed data are from the EML SASP database and are averaged into $10^{\circ}$ latitude bins. Observations from sites with elevation higher than $500 \mathrm{~m}$ are not included because of uncertainties involved in sampling coarse-resolution models at high elevation sites. Model results are sampled at observation locations on a monthly basis. Figure $5 \mathrm{~b}$ shows the annual zonal mean surface ${ }^{7} \mathrm{Be}$ concentrations in the model to indicate the global representativeness of the averages over the sampling sites. The observations indicate concentration maxima in the subtropics associated with subsidence and minima in the tropics. The tropical minimum reflects rapid scavenging within the ITCZ. Low ${ }^{7} \mathrm{Be}$ concentrations are also observed at mid-latitudes due to efficient scavenging in the mid-latitude storm tracks. Latitudinal trends (i.e., minima and maxima) of ${ }^{7} \mathrm{Be}$ concentrations are well simulated with all meteorological fields except GISS II'. The GMI/GISS simulation shows too high ${ }^{7} \mathrm{Be}$ concentrations at high latitudes; this is because of the well-known excessive cross-tropopause transport at high latitudes in the GISS II' meteorological fields (e.g., Koch and Rind, 1998; McLinden et al., 2000; Shindell et al., 2003). The overall positive biases in all simulations are partly due to our correction of the longterm records of ${ }^{7} \mathrm{Be}$ observations (by a factor of 0.72 ) to the 1958 solar maximum source (Sect. 2.5). We find that without this correction, the biases would be significantly reduced.

Figure $5 \mathrm{c}$ compares the model-simulated annual mean total deposition fluxes of ${ }^{7} \mathrm{Be}$ at 25 northern mid-latitude sites from which long-term records of observations are available. The ${ }^{7} \mathrm{Be}$ deposition flux observations are from the compilation of Koch et al. (1996), previously used in Liu et al. (2001). The data from individual sites are averaged over $4^{\circ}$ latitude bins. The model is sampled at observation locations. Figure $5 \mathrm{~d}$ shows the annual zonal mean total deposition fluxes of ${ }^{7} \mathrm{Be}$ in the model to indicate the global representativeness of the sites. The observations show a maximum $\left(\sim 2100 \mathrm{~Bq} \mathrm{~m}^{-2} \mathrm{yr}^{-1}\right)$ in the subtropics $\left(\sim 30^{\circ} \mathrm{N}\right)$ and the fluxes fall off with increasing latitude. The four ${ }^{7} \mathrm{Be}$ simulations show large discrepancies especially in the subtropics $\left(\sim 30^{\circ} \mathrm{N}\right)$. Overall, the GMI/fvGCM simulation agrees better with the magnitude of the observed fluxes while the GMI/GEOS4 simulation yields better latitudinal trends. GMI/GEOS4 simulates best the observations at the latitudes of $45-60^{\circ} \mathrm{N}$, but overestimates the observations by $\sim 50 \%$ at $20-40^{\circ} \mathrm{N}$. The GMI/GISS simulation overestimates the observations at higher latitudes $\left(45-60^{\circ} \mathrm{N}\right)$ by a factor of $\sim 2$. The GMI/GEOS1-STRAT simulation overestimates the observed ${ }^{7} \mathrm{Be}$ deposition fluxes at subtropical latitudes by up to a factor of $2.5\left(30^{\circ} \mathrm{N}\right)$. As with the above model-observation comparison of surface ${ }^{7} \mathrm{Be}$ concentrations, the overall positive biases in model total deposition fluxes would be lower without the correction of ${ }^{7} \mathrm{Be}$ observations (by a factor of 
(a)

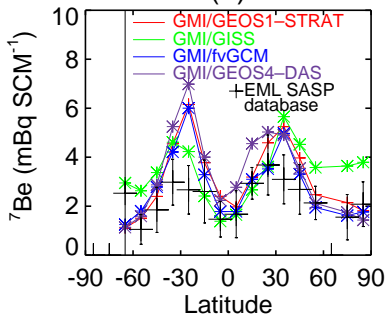

(c)

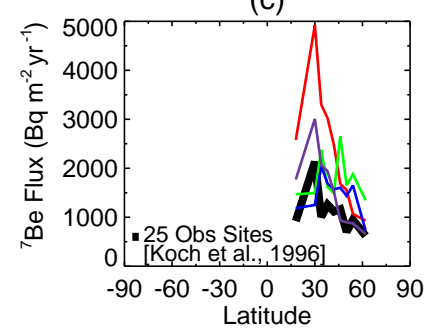

(b)

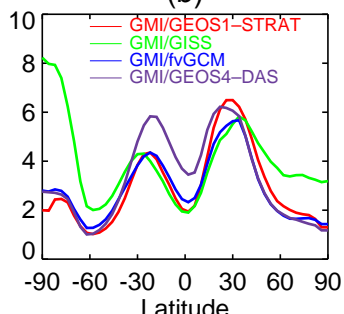

(d)

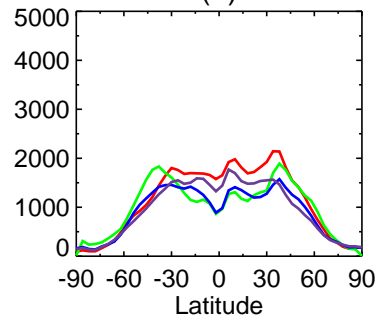

Figure 5. (a) Observed and simulated latitudinal distributions of ${ }^{7} \mathrm{Be}$ concentrations $\left(\mathrm{mBqSCM}^{-1}\right.$ ) near the surface. ${ }^{7} \mathrm{Be}$ crosstropopause fluxes were not adjusted for the GMI/GEOS1-STRAT and GMI/GISS simulations (see Sect. 3). Observed data from the EML Surface Air Sampling Program (SASP) database are averaged into $10^{\circ}$ bins. Those sites with elevation higher than $500 \mathrm{~m}$ are not included. Error bars represent \pm 2 times the standard error of the averages. Model results are sampled at observation locations and month. (b) GMI simulated annual zonal mean concentrations of ${ }^{7} \mathrm{Be}$ $\left(\mathrm{mBq} \mathrm{SCM}^{-1}\right)$ near the surface. (c) Observed (black) and GMI simulated (color) annual mean total deposition fluxes $\left(\mathrm{Bq} \mathrm{m}^{-2} \mathrm{yr}^{-1}\right)$ of ${ }^{7} \mathrm{Be}$ (at 25 sites) as a function of latitude. The data from individual sites are averaged over $4^{\circ}$ latitude bins. The model is sampled at observation locations. (d) GMI simulated annual zonal mean total deposition fluxes $\left(\mathrm{Bq} \mathrm{m}^{-2} \mathrm{yr}^{-1}\right)$ of ${ }^{7} \mathrm{Be}$.

0.72 ) to the 1958 solar maximum source (Sect. 2.5). However, we will show in the next section that these overestimated ${ }^{7} \mathrm{Be}$ deposition fluxes are largely due to model excessive cross-tropopause transport, especially with the GEOS1STRAT and GISS II' meteorological fields.

\section{Assessment of cross-tropopause transport of ${ }^{7} \mathrm{Be}$ in different meteorological archives}

The above results indicate different levels of success with four meteorological fields in reproducing long-term records of surface and UT/LS ${ }^{7}$ Be concentrations as well as total deposition fluxes. In this section, we quantify the contribution of ${ }^{7} \mathrm{Be}$ produced in the stratosphere to tropospheric ${ }^{7} \mathrm{Be}$ concentrations and deposition fluxes, followed by an assessment of cross-tropopause transport of ${ }^{7} \mathrm{Be}$ in the meteorological fields used.

Figure 6a shows the stratospheric fraction (\%) of annual zonal mean atmospheric ${ }^{7} \mathrm{Be}$ concentrations (i.e., fraction of atmospheric ${ }^{7} \mathrm{Be}$ produced in the stratosphere) in the model simulations as a function of latitude and pressure. The frac-

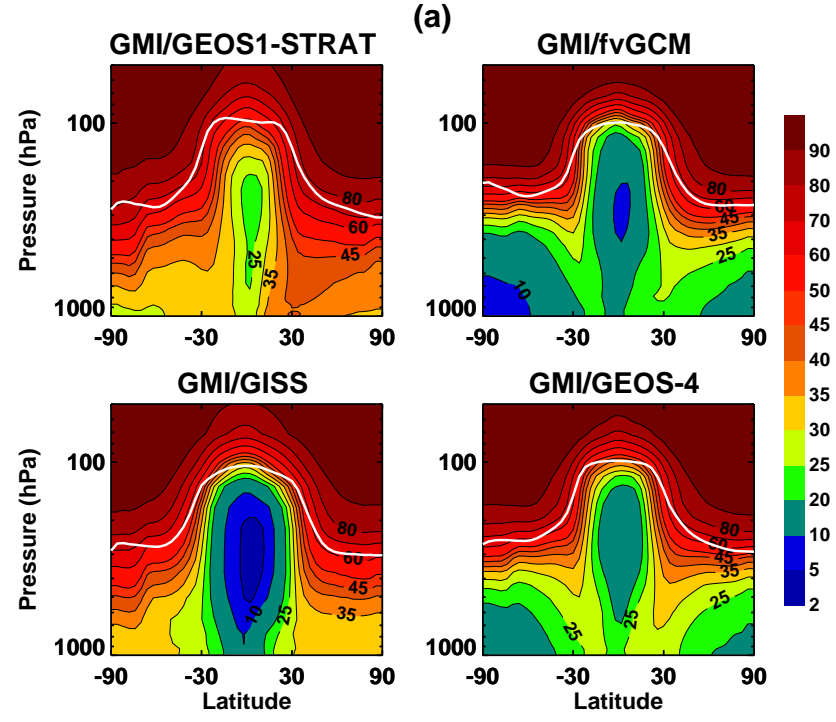

(b)

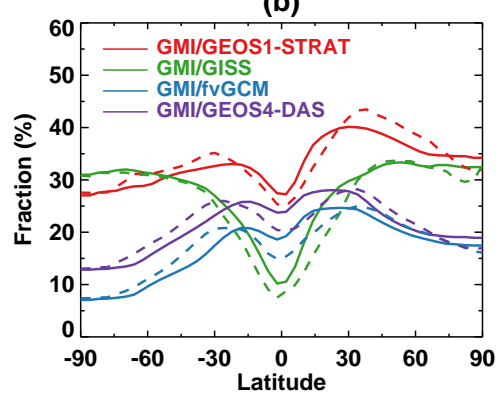

Figure 6. (a) Stratospheric fraction (\%) of annual zonal mean atmospheric ${ }^{7} \mathrm{Be}$ concentrations in the model simulations as a function of latitude and pressure. The white lines indicate thermal tropopause height. (b) Stratospheric fraction of annual zonal mean surface ${ }^{7} \mathrm{Be}$ concentrations (solid lines) and that of annual zonal mean ${ }^{7} \mathrm{Be}$ total deposition fluxes (dashed lines) in the model simulations as a function of latitude.

tions of significantly less than $100 \%$ in the lower stratosphere in all four simulations reflect mainly the seasonal movement of the tropopause. With GEOS1-STRAT, stratospheric contribution to lower-tropospheric ${ }^{7} \mathrm{Be}$ concentrations maximizes at $25-50^{\circ} \mathrm{N}(35-45 \%)$ and $25-40^{\circ} \mathrm{S}(30$ $35 \%)$. The tropical middle and upper troposphere show the minimum in stratospheric impact $(<30 \%)$. With GISS II', the stratospheric contribution to lower-tropospheric ${ }^{7} \mathrm{Be}$ concentrations peaks $(30-40 \%)$ at southern high latitudes and remains nearly constant $(30-35 \%)$ north of $30^{\circ} \mathrm{N}$ while it is quite small $(<\sim 10-20 \%)$ in the tropical middle and upper troposphere. The strong gradients in the subtropics suggest that the tropics are strongly isolated from the mid-latitudes in the GISS II' meteorological field. fvGCM and GEOS4-DAS show a similar pattern of stratospheric influence on the troposphere; both indicate maximum contribution from stratosphere near $30-35^{\circ} \mathrm{N}(\sim 25 \%)$ and $25-30^{\circ} \mathrm{S}(\sim 20-25 \%)$ in the lower troposphere. However, GEOS4-DAS shows larger 
contributions from the stratosphere to the troposphere (especially the free troposphere) than fvGCM does by a few percent, consistent with the overestimated deposition fluxes at $20-40^{\circ} \mathrm{N}$ by GEOS4-DAS (Fig. 5c). The area of minimal stratospheric influence in the tropics is also narrower in GEOS4-DAS.

Figure $6 \mathrm{~b}$ shows the stratospheric fraction $(\%)$ of annual zonal mean surface ${ }^{7} \mathrm{Be}$ concentrations and that of annual zonal mean ${ }^{7} \mathrm{Be}$ total deposition fluxes $\left(\mathrm{Bq} \mathrm{m}^{-2} \mathrm{yr}^{-1}\right)$ in the model simulations as a function of latitude. With all meteorological fields except GISS II', maximum stratospheric contribution to total deposition fluxes (vs. surface ${ }^{7} \mathrm{Be}$ concentrations) is shifted toward higher latitudes, reflecting scavenging by frequent mid-latitude precipitation and the dry subsidence in the subtropics. Stratospheric fractions of surface ${ }^{7} \mathrm{Be}$ concentrations at $\mathrm{NH}$ mid-latitude are about $38 \%$ (GEOS1-STRAT), $33 \%$ (GISS II'), and 23-24\% (fvGCM and GEOS4-DAS). As discussed in Sect. 2.4, the observed ${ }^{7} \mathrm{Be} /{ }^{90} \mathrm{Sr}$ ratio suggests that $23-27 \%$ of the ${ }^{7} \mathrm{Be}$ in surface air at northern mid-latitudes is of stratospheric origin (DH85). According to this constraint, cross-tropopause transport of ${ }^{7} \mathrm{Be}$ and subsequent transport to the surface in the GEOS1-STRAT and GISS II' meteorological fields is excessive. On the other hand, it should be noted that the fvGCM and GEOS4-DAS simulations show results remarkably consistent with the DH85 constraint, suggesting that stratospheric influences on surface ${ }^{7} \mathrm{Be}$ concentrations in these two meteorological fields are reasonable. However, DH85 did not provide constraints on latitudinal variation of stratospheric influence on surface ${ }^{7} \mathrm{Be}$. Of the four meteorological fields, GEOS1-STRAT, fvGCM and GEOS4-DAS show very similar latitudinal distribution of stratospheric influence at the surface (i.e., peak in the subtropics and valley in the tropics or polar regions). By contrast, GISS II' shows the largest impact of the stratosphere at high latitudes.

Similarly, as shown above, the model overestimates the long-term records of ${ }^{7} \mathrm{Be}$ deposition flux observations at midlatitudes (and subtropics) with GEOS1-STRAT and at high latitudes with GISS II' (Fig. 5c). Interestingly, the fvGCM (and to a lesser extent GEOS4-DAS) simulation yields ${ }^{7} \mathrm{Be}$ deposition fluxes close to the observations. This suggests that the DH85 constraint and observed ${ }^{7} \mathrm{Be}$ deposition fluxes are two complementary constraints on cross-tropopause transport of ${ }^{7} \mathrm{Be}$. We therefore use the DH85 constraint to assess the cross-tropopause transport of ${ }^{7} \mathrm{Be}$ in the meteorological fields.

Using the approach described in Sect. 2.4 (i.e., reduced cross-tropopause transport flux by artificially scaling down the stratospheric ${ }^{7} \mathrm{Be}$ source in the simulation of tropospheric ${ }^{7} \mathrm{Be}$ ), we determine the scaling factors for GEOS1-STRAT and GISS to be 1.92 and 1.35 , respectively. With the adjustment of ${ }^{7} \mathrm{Be}$ cross-tropopause fluxes for GEOS1-STRAT and GISS, the model calculated stratospheric fraction of ${ }^{7} \mathrm{Be}$ concentrations in surface air at $\mathrm{NH}$ mid-latitudes is indeed close to $25 \%$ (i.e., agree with the DH85 constraint) (Fig. 7),

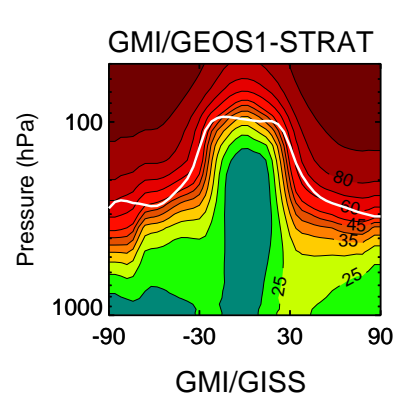

(a)

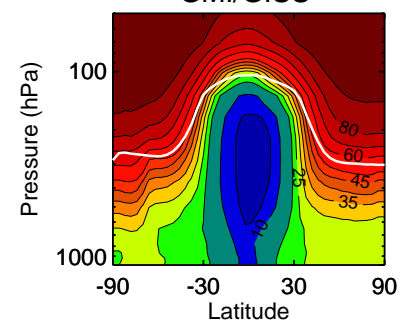

GMl/fvGCM
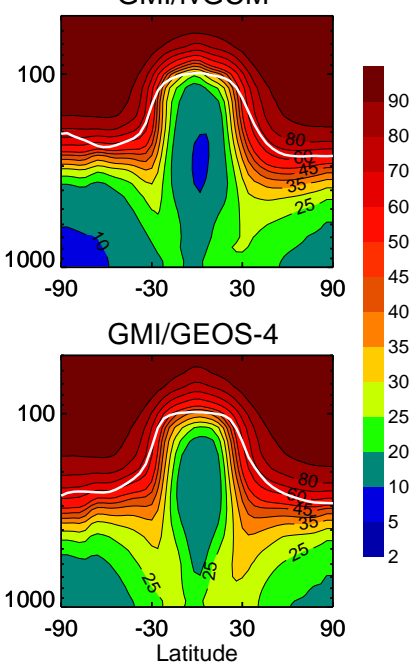

(b)

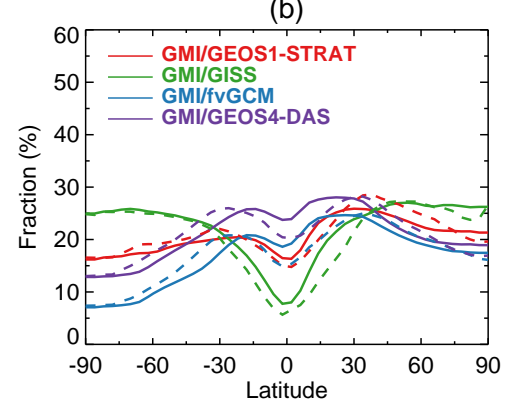

Figure 7. Same as Fig. 6, except that ${ }^{7}$ Be cross-tropopause fluxes have been adjusted for GMI/GEOS1-STRAT and GMI/GISS.

thus supporting the validity of Eq. (5). With the adjustment, some simulations also simulate better surface ${ }^{7} \mathrm{Be}$ concentrations and total deposition fluxes at the subtropics (GEOS1STRAT) and at high latitudes (GISS II') (Fig. 8 vs. Fig. 5). The improvement is clearer for total deposition fluxes than for surface concentrations. As discussed below, on a global scale total deposition fluxes are sensitive to STE fluxes of ${ }^{7} \mathrm{Be}$ into the troposphere, while surface concentrations are principally dependent on the overall wet removal rate.

Table 3 shows the annual average global budgets of tropospheric ${ }^{7} \mathrm{Be}$ in the four GMI simulations. With an adjustment of ${ }^{7} \mathrm{Be}$ cross-tropopause fluxes, the global burdens and residence times of tropospheric ${ }^{7} \mathrm{Be}$ in GMI/GEOS1-STRAT and GMI/GISS are reduced. In GMI/GEOS1-STRAT the source and sink terms become much closer to that in fvGCM and GEOS4-DAS. A reduction of global ${ }^{7} \mathrm{Be}$ STE fluxes of $0.04 \mathrm{~g} \mathrm{day}^{-1}$ results in a decrease of total deposition fluxes of $0.03 \mathrm{~g} \mathrm{day}^{-1}$ and radioactive decay of $0.01 \mathrm{~g} \mathrm{day}^{-1}$. In GMI/GISS the changes in the budget terms are relatively small due to the smaller adjustment of ${ }^{7} \mathrm{Be}$ cross-tropopause fluxes. Nevertheless, a reduction of global ${ }^{7} \mathrm{Be}$ STE fluxes of $0.01 \mathrm{~g} \mathrm{day}^{-1}$ results in a decrease of total deposition fluxes 
Table 3. Annual average global budget of ${ }^{7} \mathrm{Be}$ in the model troposphere. The GMI model was driven by the GEOS1-STRAT, GISS II', fvGCM, and GEOS4-DAS meteorological data sets, respectively.

\begin{tabular}{lrrrr}
\hline & GEOS1-STRAT & GISS & fvGCM & GEOS4-DAS \\
\hline Burden, g & $4.95(3.86)^{\mathrm{b}}$ & $4.00(3.64)^{\mathrm{b}}$ & 4.31 & 4.05 \\
Residence time, days $^{\mathrm{a}}$ & $31(29)$ & $31(30)$ & 35 & 31 \\
Sources, g day $^{-1}$ & $0.22(0.18)$ & $0.18(0.17)$ & 0.18 & 0.19 \\
$\quad$ STE & $0.08(0.04)$ & $0.05(0.04)$ & 0.04 & 0.05 \\
$\quad$ troposphere & $0.14(0.14)$ & $0.13(0.13)$ & 0.14 & 0.14 \\
Sinks, g day $^{-1}$ & $0.22(0.18)$ & $0.18(0.17)$ & 0.18 & 0.19 \\
$\quad$ dry deposition $_{\text {wet deposition }}$ & $0.01(0.01)$ & $0.01(0.01)$ & 0.01 & 0.02 \\
$\quad$ radioactive decay & $0.15(0.12)$ & $0.12(0.11)$ & 0.11 & 0.12 \\
\hline
\end{tabular}

a Against deposition only. The tropopause was determined in the model using a criterion of $2{ }^{\circ} \mathrm{Ckm}^{-1}$ lapse rate as defined by World Meteorological Organization. The diagnosed tropopause model layer was included as part of the troposphere.

${ }^{b}$ The numbers in the brackets indicate the values when ${ }^{7} \mathrm{Be}$ cross-tropopause fluxes were adjusted for GMI/GEOS1-STRAT and GMI/GISS. See text for details.

(a)

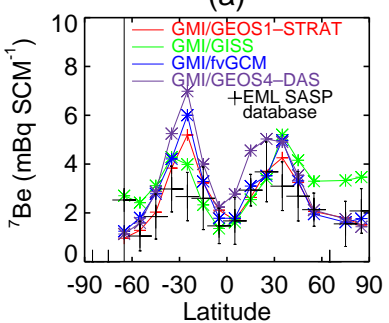

(c)

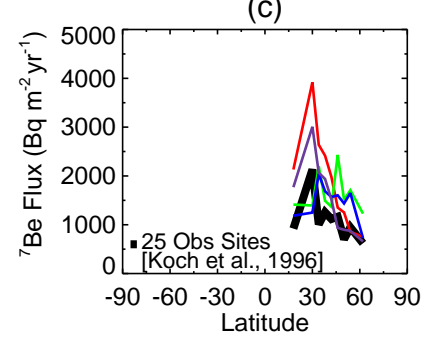

Figure 8. Same as Fig. 5, except that ${ }^{7}$ Be cross-tropopause fluxes have been adjusted for GMI/GEOS1-STRAT and GMI/GISS.

of $0.01 \mathrm{~g} \mathrm{day}^{-1}$. These calculations indicate that globally the ${ }^{7} \mathrm{Be}$ total deposition fluxes are sensitive to STE fluxes of ${ }^{7} \mathrm{Be}$ into the troposphere.

The model calculated stratospheric fraction of ${ }^{7} \mathrm{Be}$ in the troposphere may be sensitive to the model diagnosed location of the tropopause, for which there is some uncertainty. For instance, Stajner et al. (2008) used four different definitions of the tropopause on the basis of temperature lapse rate (World Meteorological Organization or WMO definition), potential vorticity (PV), and isentropic surfaces or ozone surfaces. They found that the WMO tropopause was about $0.7-1 \mathrm{~km}$ (in the northern mid-latitude) or $0.5-1 \mathrm{~km}$ (in the tropics) higher than the ozone or PV determined tropopause. We examine the sensitivity of model diagnosed stratospheric fraction of tropospheric ${ }^{7} \mathrm{Be}$ concentrations to the location of tropopause (not shown) by lowering tropopause height by one model level (approximately 1.2, 1.7, 1.1, and $1.1 \mathrm{~km}$ for GEOS1-STRAT, GISS II', fvGCM and GEOS4-DAS, respectively). Results indicate that stratospheric fractions of surface ${ }^{7} \mathrm{Be}$ concentrations increase by $5-10 \%$, thus requiring larger adjustments of cross-tropopause transport of ${ }^{7} \mathrm{Be}$ in the meteorological fields in order to meet the DH85 constraint. This also suggests that using the DH85 constraint requires relatively high vertical resolution near tropopause in the model.

While the model diagnosed stratospheric fraction of tropospheric ${ }^{7} \mathrm{Be}$ concentrations is mainly determined by the STE processes in the UT/LS, it may also be sensitive to precipitation scavenging and convective transport in the troposphere. Figure 9 shows the latitude-pressure cross sections of the differences in the stratospheric fraction (\%) of annual zonal mean tropospheric ${ }^{7} \mathrm{Be}$ concentrations between the standard simulation and a simulation where precipitation scavenging is turned off. Also shown are the corresponding differences near the surface. The stratospheric fraction of tropospheric ${ }^{7} \mathrm{Be}$ is found to be only weakly dependent on precipitation scavenging, with $<5 \%$ change in most of the troposphere and $<2.5 \%$ change near the mid-latitude surface. Figure 10 shows a similar plot, except that convective transport and scavenging are turned off in the sensitivity simulation. Similarly, the stratospheric fraction of tropospheric ${ }^{7} \mathrm{Be}$ is not sensitive to convective transport and scavenging processes, with $<1 \%$ changes near the mid-latitude surface.

\section{Comparison with previous modeling studies}

In this section we compare the GMI CTM results for crosstropopause transport of ${ }^{7} \mathrm{Be}$ with previous modeling studies based on the same or similar meteorological fields. 


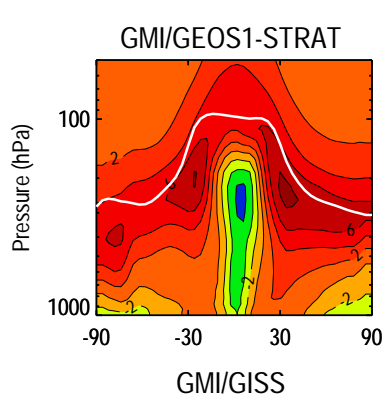

(a)
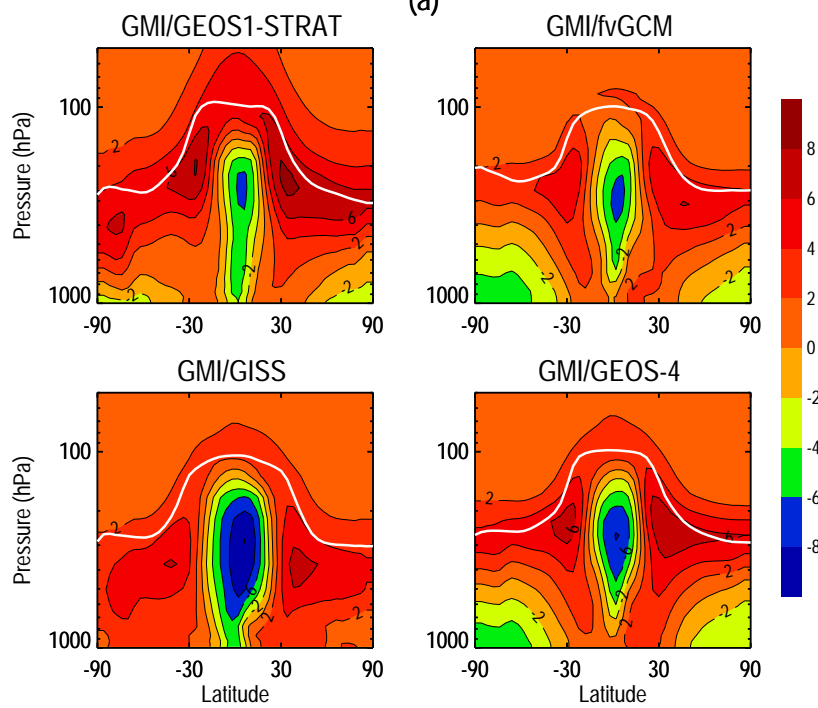

(b)

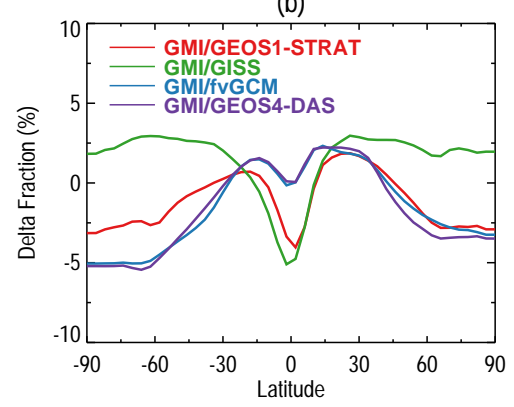

Figure 9. Same as Fig. 6a, b, except for the differences in the stratospheric fraction (\%) of zonal mean atmospheric ${ }^{7} \mathrm{Be}$ concentrations between the standard simulation and a simulation where wet scavenging is turned off.

Liu et al. (2001) found that STE flux of ${ }^{7} \mathrm{Be}$ was overestimated with the GEOS1-STRAT fields in the GEOS-Chem model, consistent with this study using GMI CTM. However, Liu et al. (2001) found that the reduction required to match the DH85 constraint is a factor of 3.5 for the GEOS1STRAT archive with $4^{\circ} \times 5^{\circ}$ resolution, compared to a factor of 1.92 in the present study. The larger reduction in the former reflects the inclusion of ice particle gravitational settling effect, which results in increased transport from the upper to lower troposphere, as well as the inclusion of the diagnosed tropopause model layer as part of the stratosphere (vs. the troposphere). Interestingly, when specifying ozone concentrations in the lower stratosphere $(70 \mathrm{hPa})$ and letting the model (GEOS-Chem) transport this ozone as an inert tracer into the troposphere, Bey et al. (2001) found a similar overestimate in an ozone simulation with the GEOS-1 data, as diagnosed by the simulation of tropospheric ozone concentrations at high latitudes in winter where transport from the stratosphere is a major source. This indicates that the simulation's deficiency in cross-tropopause transport as diagnosed using

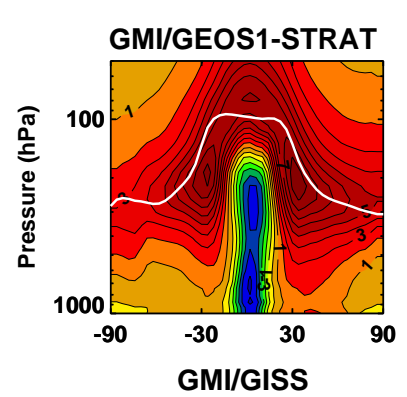

(a)
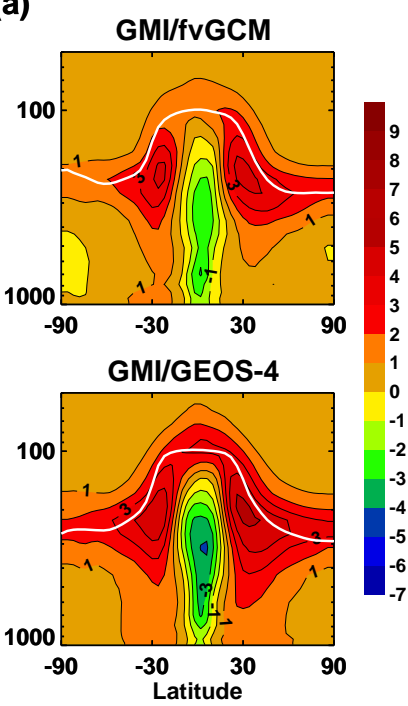

(b)

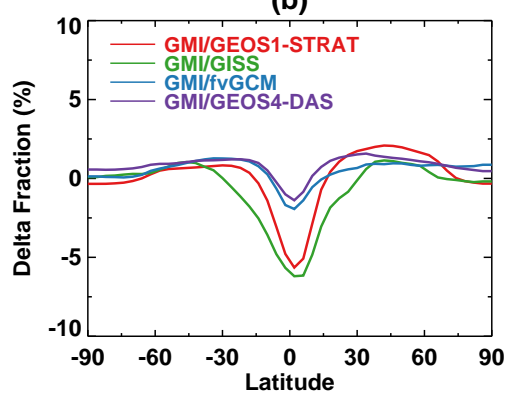

Figure 10. Same as Fig. 6a, b, except for the differences in the stratospheric fraction (\%) of zonal mean atmospheric ${ }^{7}$ Be concentrations between the standard simulation and a simulation where convective transport and scavenging are turned off.

${ }^{7} \mathrm{Be}$ tracers has similar consequences for cross-tropopause transport of ozone.

Koch and Rind (1998) used a 31-layer version of the GISS GCM to simulate ${ }^{7} \mathrm{Be}$ and ${ }^{10} \mathrm{Be}$ and used tropospheric ${ }^{10} \mathrm{Be} /{ }^{7} \mathrm{Be}$ as indicator of STE. Based on limited observations, they suggested that leakage into the troposphere is somewhat excessive in the model, particularly at high latitudes. Using the GISS II' GCM, McLinden et al. (2000) found that a large fraction of the cross-tropopause transport of ozone occurs at the poles which is inconsistent with the current understanding of stratosphere-troposphere exchange, despite the fact that the global stratosphere-troposphere exchange fluxes of ozone compare well with their best estimate of $475 \pm 120 \mathrm{Tg}_{\text {year }}{ }^{-1}$ based on measurements and tracer-tracer correlation. Shindell et al. (2003) presented an updated version of the GISS II' climate model which still overestimates ozone in the middle troposphere at high latitudes, likely reflecting deficiencies in the model's downward transport of stratospheric air. Our conclusions about crosstropopause transport of ${ }^{7} \mathrm{Be}$ in GISS II' in this work are con- 
sistent with these previous studies. Overestimated STE fluxes of ${ }^{7} \mathrm{Be}$ as diagnosed in GMI/GISS based on the DH85 constraint simply reflect the incorrect latitudinal distribution of cross-tropopause transport, that is, too fast STE at higher latitudes and too slow STE at lower latitudes. The DH85 constraint was only applicable and applied for NH mid-latitude surface and thus does not provide constraint on the model global STE flux of ${ }^{7} \mathrm{Be}$ if the latitudinal distribution of STE is incorrect.

The large-scale stratospheric transport (Brewer-Dobson circulation) in fvGCM has been shown to be realistic (Douglass et al., 2003) and mean age of stratospheric air is similar to observations (Strahan and Douglass, 2004; Douglass et al., 2008; Strahan et al., 2009). This suggests credible cross-tropopause transport of mass and ozone in fvGCM because the large-scale exchange between the stratosphere and troposphere is largely tied to the Brewer-Dobson circulation through the overworld wave driving (Holton et al., 1995; Olsen et al., 2004). Based on this finding, the meteorological data from fvGCM were used to drive GMI CTM by several authors to study tropospheric ozone. Considine et al. (2008) evaluated near-tropopause ozone distributions with ozonesonde data. Terao et al. (2008) examined the role of variability in the input of stratospheric ozone on the interannual variability of tropospheric ozone in the northern extratropics. Liang et al. (2009) investigated the impact of stratosphere-to-troposphere transport on tropospheric ozone and $\mathrm{NO}_{x}$ chemistry over the Arctic. By contrast, GEOS4DAS tends to have too strong a residual circulation, and the age of air is too young compared to observations (Schoeberl et al., 2003; Schoeberl, 2004; Douglass et al., 2008). A GMI CTM simulation driven with the GEOS4-DAS meteorological fields showed the model's inadequacy in simulating upper-tropospheric ozone (Liang et al., 2009). These findings are consistent with what we illustrated in this study from a perspective of ${ }^{7} \mathrm{Be}$ tracers. That is, GEOS4-DAS features a larger impact of STE on the troposphere (especially UT) than fvGCM does, while the latter has more credible cross-tropopause transport as constrained by observed ${ }^{7} \mathrm{Be}$ deposition fluxes (Fig. 5c) and the DH85 criterion (Fig. 6).

\section{Implications for cross-tropopause transport of ozone}

In this section we discuss the implications of different characteristics of cross-tropopause transport of ${ }^{7} \mathrm{Be}$ for stratospheric influence on tropospheric ozone in different meteorological fields. At the time of this study, the GMI full-chemistry model can be driven with GEOS1-STRAT, fvGCM and GEOS4-DAS, but not GISS II' meteorological fields. This allows us to examine any potential relationship between the cross-tropopause transport of ${ }^{7} \mathrm{Be}$ and ozone when these fields are used to drive the model.
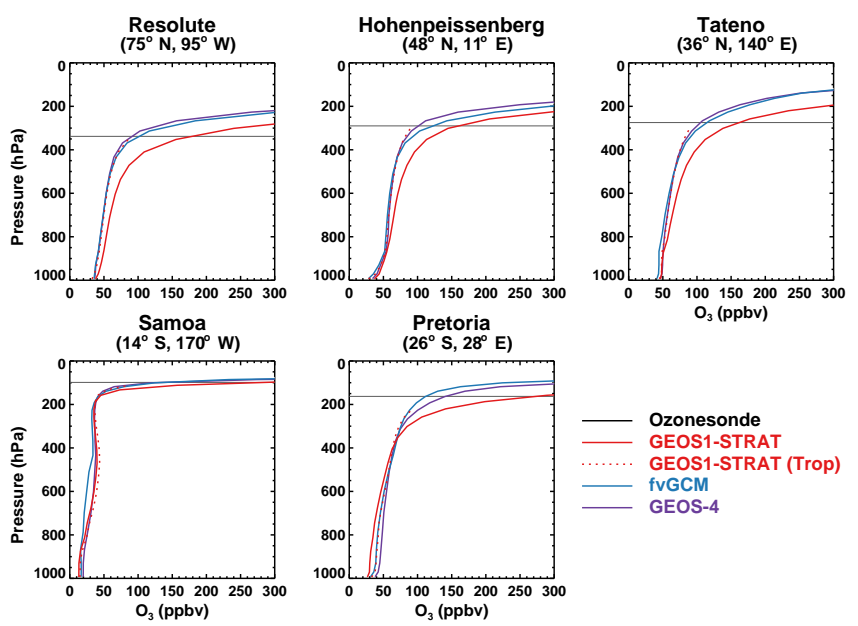

Figure 11. Comparisons of GMI simulated tropospheric ozone profiles (color lines) with ozonesonde observations (black line) for a range of latitudes. Values are annual averages. Solid color lines indicate the GMI simulations. Also shown as dotted lines are tropospheric ozone profiles as simulated by the GMI tropospheric model driven by the GEOS1-STRAT meteorological field. The horizontal gray line indicates the approximate location of tropopause (i.e., the pressure level corresponding to $100 \mathrm{ppbv}$ ozone concentrations in the ozonesonde observations).

Ozonesonde, surface and satellite observations provide useful constraints on the stratospheric contribution to tropospheric ozone (e.g., Rind et al., 2007; Lin et al., 2012). Figure 11 shows comparisons of model tropospheric ozone profiles with annual mean ozonesonde observations for a range of latitudes (Considine et al., 2008). These results are typical of other stations at similar latitudes. The GMI/GEOS1STRAT simulation produces excessive ozone throughout the troposphere at all latitudes except in the tropics while the GMI/fvGCM and GMI/GEOS4-DAS simulations are generally in agreement with the observations (with slightly overpredicted ozone in the mid-latitude upper troposphere). The GEOS1-STRAT simulation has the largest overestimate of $\mathrm{O}_{3}$ in spring. We also compared model surface ozone concentrations with the Logan (1999) surface ozone data set (not shown). Among the three GMI simulations, the GMI/GEOS1-STRAT simulation shows the largest errors in surface ozone concentrations during winter and spring when stratospheric contribution is at its peak. These are in line with the relative magnitudes of cross-tropopause transport efficiencies of ${ }^{7} \mathrm{Be}$ in the three meteorological fields (i.e., too fast STE in GEOS1-STRAT), discussed in previous sections. Indeed, the tropospheric version of the GMI/GEOS1-STRAT model with constrained STE flux of ozone using the Synoz approach (about $579 \mathrm{Tg}_{\text {year }}{ }^{-1}$ ) simulates ozonesonde observations of tropospheric ozone reasonably well (dotted line, Fig. 11).

Figure 12 shows GMI simulated annual zonal mean tropospheric ozone column (TOC), in Dobson Units, compared 


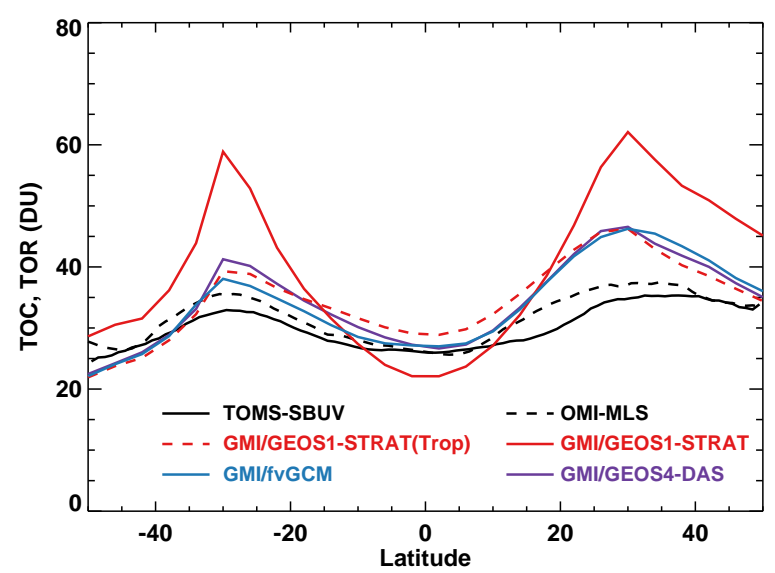

Figure 12. GMI simulated annual zonal mean tropospheric ozone column (TOC in Dobson Units) compared with observed tropospheric ozone residuals from TOMS/SBUV (1979-2005 average) and OMI/MLS (October 2004-July 2008 average). Also shown is the annual zonal mean TOC simulated by the tropospheric version of the GMI model.

with observed climatologies from TOMS/SBUV (19792005; Fishman et al., 2003) and OMI/MLS (October 2004July 2008; Ziemke et al., 2006). The WMO definition of thermal tropopause is used to calculate the model TOC. While the GMI/fvGCM and GMI/GEOS4-DAS simulations are similar and overestimate TOC by up to $\sim 20 \mathrm{DU}$, the GMI/GEOS1-STRAT simulation overestimates TOC by as much as $\sim 40 \mathrm{DU}$. The excessive $\mathrm{O}_{3}$ in the GMI/GEOS1STRAT simulation with maxima at $30^{\circ} \mathrm{N}$ and $30^{\circ} \mathrm{S}$ suggests downward transport of ozone from the stratosphere is too fast. The tropospheric version of the GMI/GEOS1-STRAT model with constrained STE flux of ozone provides a much better simulation of global TOCs (red dashed line, Fig. 12), which are comparable to those from GMI/fvGCM and GMI/GEOS4-DAS simulations. However, model TOCs are still 10-14 DU larger than satellite observations in the subtropics and mid-latitudes. Previously, Ziemke et al. (2006) considered uncertainties in both model and observations and subjectively interpreted model-OMI/MLS TOC differences of $10 \mathrm{DU}$ and higher as being significant. As Stajner et al. (2008) noted, a low extratropical tropopause used by Ziemke et al. (2006) may have played an important role in the underestimation of OMI/MLS TOC. Yang et al. (2010) also found that their OMI/MLS potential vorticity mapped TOCs are smaller than ozonesonde TOCs by $5.9 \mathrm{DU}$ with a standard deviation of the differences of 8.4 DU. On the other hand, the GMI/fvGCM simulation tends to overestimate ozone just below the tropopause at mid-latitudes (Fig. 11); these biases do not appear to be due to excessive stratospheric influence (Considine et al., 2008). Current global models also tend to overpredict surface ozone during summer and early fall over the eastern US and Japan (Fiore et al., 2009). Therefore the simulated TOCs are very likely biased high.
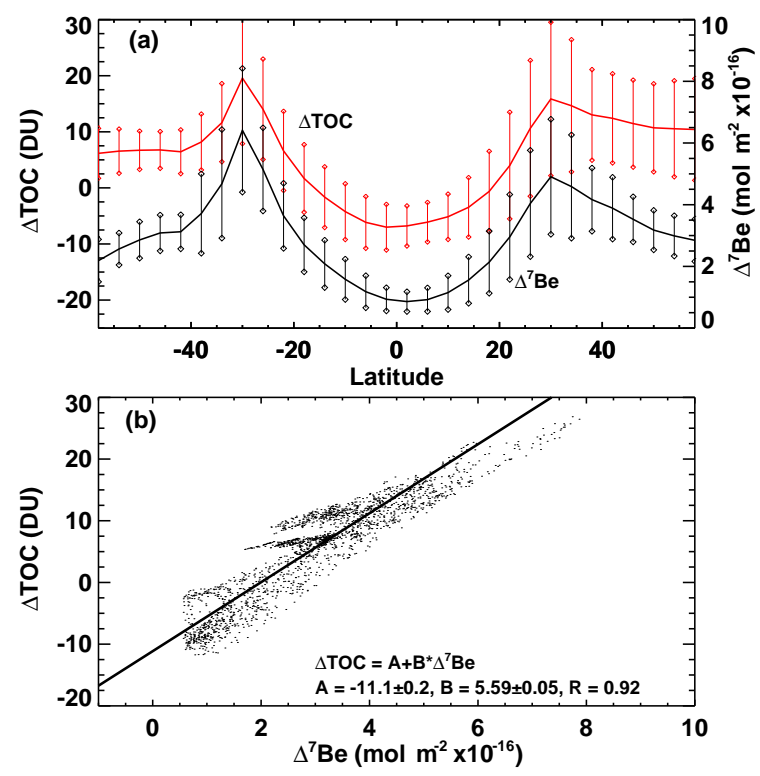

Figure 13. (a) Latitudinal variations of annual zonal mean ${ }^{7} \mathrm{Be}$ overestimate $\left(\Delta^{7} \mathrm{Be}\right)$ and tropospheric ozone column overestimate ( $\triangle$ TOC) as simulated by GMI/GEOS1-STRAT. Error bars represent \pm 2 times the standard error of the averages. (b) The correlation between the global distributions of $\Delta^{7} \mathrm{Be}$ and $\triangle \mathrm{TOC}$. The lines of best fit are calculated using the reduced-major-axis (RMA) method (Hirsch and Gilroy, 1984). See text for details.

We further examine the relationship between the crosstropopause transport of ${ }^{7} \mathrm{Be}$ and ozone with the GEOS1STRAT meteorological fields, in which case STE is known to be too fast. Figure 13a shows the latitudinal variations of annual zonal mean tropospheric ${ }^{7} \mathrm{Be}$ column overestimate $\left(\Delta^{7} \mathrm{Be}\right)$ and TOC overestimate $(\triangle \mathrm{TOC})$ in the GMI/GEOS1STRAT simulation. $\Delta^{7} \mathrm{Be}$ is obtained by subtraction of the STE-flux-adjusted simulation (Sect. 2.4) from the standard simulation. $\triangle \mathrm{TOC}$ is obtained by subtracting the GMI tropospheric model simulation (with STE flux of ozone about $579 \mathrm{Tg} \mathrm{year}^{-1}$ ) from the GMI full-chemistry model simulation. Figure 13b shows the correlation between the global distributions of $\Delta^{7} \mathrm{Be}$ and $\Delta \mathrm{TOC}$. The lines of best fit are calculated using the reduced-major-axis (RMA) method (Hirsch and Gilroy, 1984). Standard errors for the intercept and the slope are computed as described by Miller and Kahn (1962). Overall, the location of overestimated ozone follows that of overestimated ${ }^{7} \mathrm{Be}$, with both maxima near $30^{\circ} \mathrm{N}$ and $30^{\circ} \mathrm{S}$. The strong correlation between $\Delta^{7} \mathrm{Be}$ and $\Delta \mathrm{TOC}$ implies that ${ }^{7} \mathrm{Be}$ is a good indicator of cross-tropopause transport of ozone. These support our conclusion that ${ }^{7} \mathrm{Be}$ is a useful utility for assessing cross-tropopause transport of ozone in global models. 


\section{$7 \quad$ Summary and conclusions}

We have assessed the ability of the Global Modeling Initiative (GMI) chemical transport model (CTM) using different meteorological data sets to simulate the atmospheric distributions of ${ }^{7} \mathrm{Be}$, a natural aerosol tracer originating from the upper troposphere and/or lower stratosphere and removed from the troposphere primarily by wet deposition. The model was driven by four meteorological data sets (GEOS1-STRAT, GISS II', fvGCM, GEOS4-DAS) which feature significantly different cross-tropopause transport characteristics. The GMI modeling framework was configured such that the variability between the simulations mainly reflects the use of different meteorological data. Our goal was to assess the utility of ${ }^{7} \mathrm{Be}$ as a tracer of cross-tropopause transport in global models and develop a methodology to exploit such a utility. We have also discussed the implications of excessive cross-tropopause transport as revealed by ${ }^{7} \mathrm{Be}$ simulations for the modeling of tropospheric ozone.

We evaluated the four simulations of ${ }^{7} \mathrm{Be}$ with RANDAB, a unique database of upper atmosphere radionuclide climatological observations compiled by the DOE (now DHS) Environmental Measurement Laboratory, as well as longterm measurements at the surface. Model simulations capture the UT/LS observations with respect to latitudes. The GMI/GEOS1-STRAT simulation shows the lowest ${ }^{7} \mathrm{Be}$ concentrations among the four simulations in the lower stratosphere, and underestimates the observations. This reflects the well-known highly overestimated cross-tropopause transport in GEOS1-STRAT DAS. At the surface, GMI/GISS II' reproduces the observed latitudinal trends of ${ }^{7} \mathrm{Be}$ concentrations, but shows too high concentrations at high latitudes. The GMI/fvGCM simulated ${ }^{7} \mathrm{Be}$ deposition fluxes are the closest to the observations, while the GMI/GEOS1-STRAT overestimates the observed ${ }^{7} \mathrm{Be}$ deposition fluxes at subtropical latitudes by up to a factor of $2.5\left(30^{\circ} \mathrm{N}\right)$ and the GMI/GISS simulations at high latitudes $\left(45-60^{\circ} \mathrm{N}\right)$ are a factor of 2 too high. We were able to show that the observed ${ }^{7} \mathrm{Be}$ deposition fluxes offer a strong constraint on stratosphere-totroposphere transport in global models.

We examined the observational constraint from Dutkiewicz and Husain (1985) (DH85) on the stratospheric contribution to tropospheric ${ }^{7} \mathrm{Be}$ using the GMI modeling framework. DH85 analyzed the observed ${ }^{7} \mathrm{Be} /{ }^{90} \mathrm{Sr}$ ratio, which suggests that $23-27 \%$ of the ${ }^{7} \mathrm{Be}$ in surface air at northern mid-latitudes is of stratospheric origin. This constraint offers a sensitive test of cross-tropopause transport in global models. Comparison of the fraction of surface air of stratospheric origin estimated from the ${ }^{7} \mathrm{Be}$ simulations with the DH85 constraint indicates excessive cross-tropopause transport at mid-latitudes with the GEOS1-STRAT meteorological fields and at high latitudes with the GISS II fields. Interestingly, these simulations also overestimate observed ${ }^{7} \mathrm{Be}$ deposition fluxes at middle and high latitudes, respectively. With a correction to cross-tropopause flux, the model simulates better surface ${ }^{7} \mathrm{Be}$ concentrations and total deposition fluxes. By contrast, the fvGCM meteorological data yield the most reasonable cross-tropopause transport of ${ }^{7} \mathrm{Be}$ according to the DH85 constraint, consistent with the fact that the GMI/fvGCM simulated ${ }^{7} \mathrm{Be}$ deposition fluxes are closest to the observations. These results illustrate that the GMI framework is very useful for characterizing and helping to reduce uncertainties in the processes such as cross-tropopause transport in the meteorological fields that are used to drive chemical transport models. Note that since wet deposition removes both the stratospheric and tropospheric components of ${ }^{7} \mathrm{Be}$ nondiscriminatively, the model diagnosed fraction of ${ }^{7} \mathrm{Be}$ of stratospheric origin does not significantly depend on the rate of wet removal.

The model diagnosed stratospheric fraction of ${ }^{7} \mathrm{Be}$ in surface air is sensitive to the diagnosed location of tropopause, in particular when the model vertical resolution is relatively coarse $(>1-1.5 \mathrm{~km})$ near the tropopause region. This suggests that stratospheric fraction of ${ }^{7} \mathrm{Be}$ is a more useful diagnostic when the model has sufficient vertical resolution $(<1-1.5 \mathrm{~km})$ so that the tropopause can be well defined. We used the WMO definition of thermal tropopause and include the diagnosed tropopause model layer as part of the troposphere (vs. the stratosphere). As such our assessment of cross-tropopause transport of ${ }^{7} \mathrm{Be}$ in the four meteorological data sets in the GMI CTM is consistent with previous modeling studies of stratospheric influence on tropospheric ozone.

Incorrect cross-tropopause transport of ${ }^{7} \mathrm{Be}$ implies misrepresented downward influx of stratospheric ozone to the troposphere in a model. We demonstrated this by examining the relationship between the cross-tropopause transport of ${ }^{7} \mathrm{Be}$ and ozone as simulated by GMI CTM driven with GEOS1-STRAT, fvGCM and GEOS4-DAS meteorological fields. We found that excessive cross-tropopause transport of ${ }^{7} \mathrm{Be}$ corresponds to overestimated stratospheric contribution to tropospheric ozone, as constrained by ozonesonde, surface and satellite observations.

In summary, the ${ }^{7} \mathrm{Be}$ simulation, which is computationally cheap and technically simple, in combination with the DH85 ${ }^{7}$ Be observational constraint and observed ${ }^{7}$ Be deposition fluxes may be used routinely to assess cross-tropopause transport in global models. We recommend separate transport of the ${ }^{7} \mathrm{Be}$ produced in the stratosphere $\left({ }^{7} \mathrm{Be}\right.$-strat) to evaluate the ratio of ${ }^{7} \mathrm{Be}$-strat to total ${ }^{7} \mathrm{Be}$ (i.e., beryllium-7 produced in both the stratosphere and the troposphere) in surface air against the DH85 constraint. This can serve as a first-order assessment of cross-tropopause transport in the meteorological fields. With improved estimates of ${ }^{7} \mathrm{Be}$ production rates as well as their year-to-year variations, model multi-year ${ }^{7} \mathrm{Be}$ simulations together with long-term observations would provide useful constraints on the interannual variability of STE. While this study uses ${ }^{7} \mathrm{Be}$ alone, future modeling work will include using ${ }^{10} \mathrm{Be} /{ }^{7} \mathrm{Be}$, a more sensitive indicator of STE (Rehfeld and Heimann, 1995; Koch and Rind, 1998; Jordan et al., 2003). 


\section{Data availability}

A description of the data sets used in this paper and their availability can be found in Sect. 2.5.

Acknowledgements. This work was supported by the NASA Modeling, Analysis and Prediction (MAP) program, the Atmospheric Composition Modeling and Analysis Program (ACMAP), and the Atmospheric Composition Campaign Data Analysis and Modeling (ACCDAM) program. We thank Bryan Duncan for his contribution to the GMI model development, and two anonymous reviewers for constructive comments. The GMI core team at NASA GSFC is acknowledged for programming support. NASA Center for Computational Sciences (NCCS) provided supercomputing resources. The GEOS-Chem model is managed by the Atmospheric Chemistry Modeling Group at Harvard University with support from ACMAP and MAP.

Edited by: J.-U. Grooß

\section{References}

Adler, R. F.: The Version 2 Global Precipitation Climatology Project (GPCP) monthly precipitation analysis (1979-Present), J. Hydrometeorol., 4, 1147-1167, 2003.

Allen, D. J., Dibb, J. E., Ridley, B., Pickering, K. E., and Talbot, R. W.: An estimate of the stratospheric contribution to springtime tropospheric ozone maxima using TOPSE measurements and beryllium-7 simulations, J. Geophys. Res., 108, 8355, doi:10.1029/2001JD001428, 2003.

Bey, I., Jacob, D. J., Yantosca, R. M., Logan, J. A., Field, B., Fiore, A. M., Li, Q., Liu, H., Mickley, L. J., and Schultz, M.: Global modeling of tropospheric chemistry with assimilated meteorology: Model description and evaluation, J. Geophys. Res., 106, 23073-23096, 2001.

Brost, R. A., Feichter, J., and Heimann, M.: Three-dimensional simulation of ${ }^{7} \mathrm{Be}$ in a global climate model, J. Geophys. Res., 96, 22423-22445, 1991.

Collins, W. J., Derwent, R. G., Garnier, B., Johnson, C. E., and Sanderson, M. G., and Stevenson, D. S.: Effect of stratospheretroposphere exchange on the future tropospheric ozone trend, J. Geophys. Res., 108, 8528, doi:10.1029/2002JD002617, 2003.

Considine, D. B., Bergmann, D. J., and Liu, H.: Sensitivity of Global Modeling Initiative chemistry and transport model simulations of radon-222 and lead-210 to input meteorological data, Atmos. Chem. Phys., 5, 3389-3406, doi:10.5194/acp-5-33892005, 2005.

Considine, D. B., Logan, J. A., and Olsen, M. A.: Evaluation of near-tropopause ozone distributions in the Global Modeling Initiative combined stratosphere/troposphere model with ozonesonde data, Atmos. Chem. Phys., 8, 2365-2385, doi:10.5194/acp-8-2365-2008, 2008.

Cristofanelli, P., Bonasoni, P., Collins, W., Feichter, J., Forster, C., James, P., Kentarchos, A., Kubik, P. W., Land, C., Meloen, J., Roelofs, G. J., Siegmund, P., Sprenger, M., Schnabel, C., Stohl, A., Tobler, L., Tositti, L., Trickl, T., and Zanis, P.: Stratosphereto-troposphere transport: A model and method evaluation, J. Geophys. Res., 108, 8525, doi:10.1029/2002JD002600, 2003.
Dibb, J. E.: Vertical mixing above Summit, Greenland: Insights into seasonal and high frequency variability from the radionuclide tracers Be-7 and Pb-210, Atmos. Environ., 41, 5020-5030, 2007.

Dibb, J. E., Talbot, R. W., and Gregory, G. L.: Beryllium-7 and lead210 in the western hemisphere Arctic atmosphere: Observations from three recent aircraft-based sampling programs, J. Geophys. Res., 97, 16709-16715, 1992.

Dibb, J. E., Meeker, L. D., Finkel, R. C., Southon, J. R., Caffee, M. W., and Barrie, L. A.: Estimation of stratospheric input to the Arctic troposphere: ${ }^{7} \mathrm{Be}$ and ${ }^{10} \mathrm{Be}$ in aerosols at Alert, Canada, J. Geophys. Res., 99, 12855-12864, 1994.

Dibb, J. E., Talbot, R. W., Scheuer, E., Seid, G., DeBell, L., Lefer, B., and Ridley, B.: Stratospheric influence on the northern North American free troposphere during TOPSE: ${ }^{7} \mathrm{Be}$ as a stratospheric tracer, J. Geophys. Res., 108, 8363, doi:10.1029/2001JD001347, 2003.

Douglass, A. R., Prather, M. J., Hall, T. M., Strahan, S. E., Rasch, P. J., Sparling, L. C., Coy, L., and Rodriguez, J. M.: Choosing meteorological input for the Global Modeling Initiative assessment of high-speed aircraft, J. Geophys. Res., 104, 27545-27564, 1999.

Douglass, A. R., Schoeberl, M. R., Rood, R. B., and Pawson, S.: Evaluation of transport in the lower tropical stratosphere in a global chemistry and transport model, J. Geophys. Res., 108, 4259, doi:10.1029/2002JD002696, 2003.

Douglass, A. R., Stolarski, R. S., Strahan, S. E., and Connell, P. S.: Radicals and reservoirs in the GMI chemistry and transport model: Comparison to measurements, J. Geophys. Res., 109, D16302, doi:10.1029/2004JD004632, 2004.

Douglass, A. R., Stolarski, R. S., Schoeberl, M. R., Jackman, C. H., Gupta, M. L., Newman, P. A., Nielsen, J. E., and Fleming, E. L.: Relationship of loss, mean age of air and the distribution of CFCs to stratospheric circulation and implications for atmospheric lifetimes, J. Geophys. Res., 113, D14309, doi:10.1029/2007JD009575, 2008.

Duncan, B. N., Strahan, S. E., Yoshida, Y., Steenrod, S. D., and Livesey, N.: Model study of the cross-tropopause transport of biomass burning pollution, Atmos. Chem. Phys., 7, 3713-3736, doi:10.5194/acp-7-3713-2007, 2007.

Duncan, B. N., West, J. J., Yoshida, Y., Fiore, A. M., and Ziemke, J. R.: The influence of European pollution on ozone in the Near East and northern Africa, Atmos. Chem. Phys., 8, 2267-2283, doi:10.5194/acp-8-2267-2008, 2008.

Dutkiewicz, V. A. and Husain, L.: Stratospheric and tropospheric components of ${ }^{7} \mathrm{Be}$ in surface air, J. Geophys. Res., 90, 57835788, 1985.

Feely, H. W., Larsen, R. J., and Sanderson, C. G.: Factors that cause seasonal variations in beryllium-7 concentrations in surface air, J. Environ. Radioactiv., 9, 223-249, 1989.

Field, C. V., Schmidt, G. A., Koch, D., and Salyk, C.: Modeling production and climate-related impacts on ${ }^{10} \mathrm{Be}$ concentration in ice cores, J. Geophys. Res., 111, D15107, doi:10.1029/2005JD006410, 2006.

Fiore, A. M., Dentener, F. J., Wild, O., Cuvelier, C., Schultz, M. G., Hess, P., Textor, C., Schulz, M., Doherty, R. M., Horowitz, L. W., MacKenzie, I. A., Sanderson, M. G., Shindell, D. T., Stevenson, D. S., Szopa, S., Van Dingenen, R., Zeng, G., Atherton, C., Bergmann, D., Bey, I., Carmichael, G., Collins, W. J., Duncan, B. N., Faluvegi, G., Folberth, G., Gauss, M., Gong, S., Hauglustaine, D., Holloway, T., Isaksen, I. S. A., Jacob, D. J., 
Jonson, J. E., Kaminski, J. W., Keating, T. J., Lupu, A., Marmer, E., Montanaro, V., Park, R. J., Pitari, G., Pringle, K. J., Pyle, J. A., Schroeder, S., Vivanco, M. G., Wind, P., Wojcik, G., Wu, S., and Zuber, A.: Multimodel estimates of intercontinental sourcereceptor relationships for ozone pollution, J. Geophys. Res., 114, D04301, doi:10.1029/2008JD010816, 2009.

Fishman, J., Wozniak, A. E., and Creilson, J. K.: Global distribution of tropospheric ozone from satellite measurements using the empirically corrected tropospheric ozone residual technique: Identification of the regional aspects of air pollution, Atmos. Chem. Phys., 3, 893-907, doi:10.5194/acp-3-893-2003, 2003.

Graustein, W. C. and Turekian, K. K.: ${ }^{7} \mathrm{Be}$ and ${ }^{210} \mathrm{~Pb}$ indicate an upper troposphere source for elevated ozone in the summertime subtropical free troposphere of the eastern North Atlantic, Geophys. Res. Lett., 23, 539-542, 1996.

Heikkilä, U., Beer, J., and Alfimov, V.: Beryllium-10 and beryllium7 in precipitation in Dubendorf $(440 \mathrm{~m})$ and at Jungfraujoch (3580 m), Switzerland (1998-2005), J. Geophys. Res., 113, D11104, doi:10.1029/2007JD009160, 2008a.

Heikkilä, U., Beer, J., and Feichter, J.: Modeling cosmogenic radionuclides ${ }^{10} \mathrm{Be}$ and ${ }^{7} \mathrm{Be}$ during the Maunder Minimum using the ECHAM5-HAM General Circulation Model, Atmos. Chem. Phys., 8, 2797-2809, doi:10.5194/acp-8-2797-2008, 2008b.

Helmig, D., Oltmans, S. J., Morse, T. O., and Dibb, J. E.: What is causing high ozone at Summit, Greenland? Atmos. Environ., 41, 5031-5043, 2007.

Hirsch, R. M. and Gilroy, E. J.: Methods of fitting a straight line to data: Examples in water resources, Water Resour. Bull., 20, 705-711, 1984.

Holton, J. R., Haynes, P. H., McIntyre, M. E., Douglass, A. R., Rood, R. B., and Pfister, L.: Stratosphere-Troposphere Exchange, Rev. Geophys., 33, 403-439, 1995.

Hsu, J. and Prather, M. J.: Stratospheric variability and tropospheric ozone, J. Geophys. Res., 114, D06102, doi:10.1029/2008JD010942, 2009.

Hsu, J., Prather, M. J., and Wild, O.: Diagnosing the stratosphereto-troposphere flux of ozone in a chemistry transport model, J. Geophys. Res., 110, D19305, doi:10.1029/2005JD006045, 2005.

Husain, L., Coffey, P. E., Meyers, R. E., and Cederwall, R. T.: Ozone transport from stratosphere to troposphere, Geophys. Res. Lett., 4, 363-365, 1977.

Johnson, W. B. and Viezee, W.: Stratospheric ozone in the lower troposphere - I. Presentation and interpretation of aircraft measurements, Atmos. Environ., 15, 1309-1323, 1981.

Jordan, C. E., Dibb, J. E., and Finkel, R. C.: ${ }^{10} \mathrm{Be} /{ }^{7} \mathrm{Be}$ tracer of atmospheric transport and stratosphere-troposphere exchange, J. Geophys. Res., 108, 4234, doi:10.1029/2002JD002395, 2003.

Koch, D. M. and Rind, D.: Beryllium-10/beryllium-7 as a tracer of stratospheric transport, J. Geophys. Res., 103, 3907-3917, 1998.

Koch, D. M., Jacob, D. J., and Graustein, W. C.: Vertical transport of tropospheric aerosols as indicated by ${ }^{7} \mathrm{Be}$ and ${ }^{210} \mathrm{~Pb}$ in a chemical tracer model, J. Geophys. Res., 101, 18651-18666, 1996.

Koch, D., Schmidt, G. A., and Field, C. V.: Sulfur, sea salt, and radionuclide aerosols in GISS ModelE, J. Geophys. Res., 111, D06206, doi:10.1029/2004JD005550, 2006.

Kritz, M. A., Rosner, S. W., Danielsen, E. F., and Selkirk, S. B.: Air mass origins and troposphere-to-stratosphere exchanges associated with mid-latitude cyclogenesis and tropopause folding inferred from ${ }^{7}$ Be measurements, J. Geophys. Res., 96, 1740517414, 1991.

Lal, D. and Peters, B.: Cosmic ray produced radioactivity on the Earth, in: Handuch der Physik, 46/2, edited by: Sitte, K., Springer-Verlag, New York, USA, 551-612, 1967.

Langford, A. O., Senff, C. J., Alvarez II, R. J., Brioude, J., Cooper, O. R., Holloway, J. S., Lin, M. Y., Marchbanks, R. D., Pierce, R. B., Sandberg, S. P., Weickmann, A. M., and Williams, E. J.: An overview of the 2013 Las Vegas Ozone Study (LVOS): Impact of stratospheric intrusions and long-range transport on surface air quality. Atmos. Environ., 109, 305-322, doi:10.1016/j.atmosenv.2014.08.040, 2015.

Leifer, R. and Chan, N.: The Environmental Measurements Laboratory's Stratospheric Radionuclide (RANDAB) and Trace Gas (TRACDAB) Databases, available at: http://cdiac.esd.ornl.gov/ ndps/db1019.html (last access: 12 April 2016), 1997.

Li, Q., Jacob, D. J., Fairlie, T. D., Liu, H., Martin, R. V., and Yantosca, R. M.: Stratospheric vs. pollution influences on ozone at Bermuda: Reconciling past analyses, J. Geophys. Res., 107, 4611, doi:10.1029/2002JD002138, 2002.

Liang, Q., Douglass, A. R., Duncan, B. N., Stolarski, R. S., and Witte, J. C.: The governing processes and timescales of stratosphere-to-troposphere transport and its contribution to ozone in the Arctic troposphere, Atmos. Chem. Phys., 9, 30113025, doi:10.5194/acp-9-3011-2009, 2009.

Lin, M., Fiore, A. M., Cooper, O. R., Horowitz, L. W., Langford, A. O., Levy II, H., Johnson, B. J., Naik, V., Oltmans, S. J., and Senff, C. J.: Springtime high surface ozone events over the western United States: Quantifying the role of stratospheric intrusions, J. Geophys. Res., 117, D00V22, doi:10.1029/2012JD018151, 2012.

Lin, M., Fiore, A. M., Horowitz, L. W., Langford, A. O., Oltmans, S. J., Tarasick, D., and Rieder, H. E.: Climate variability modulates western U.S. ozone air quality in spring via deep stratospheric intrusions, Nature Communications, 6, 7105, doi:10.1038/ncomms8105, 2015.

Lin, S. J. and Rood, R. B.: Multidimensional flux-form semiLagrangian transport schemes, Mon. Weather Rev., 124, 20462070, 1996.

Liu, H., Jacob, D. J., Bey, I., and Yantosca, R. M.: Constraints from ${ }^{210} \mathrm{~Pb}$ and ${ }^{7} \mathrm{Be}$ on wet deposition and transport in a global threedimensional chemical tracer model driven by assimilated meteorological fields, J. Geophys. Res., 106, 12109-12128, 2001.

Liu, H., Jacob, D. J., Dibb, J. E., Fiore, A. M., and Yantosca, R. M.: Constraints on the sources of tropospheric ozone from ${ }^{210} \mathrm{~Pb}^{-}{ }^{7} \mathrm{Be}-\mathrm{O}_{3}$ correlations, J. Geophys. Res., 109, D07306, doi:10.1029/2003JD003988, 2004.

Liu, X., Penner, J. E., Das, B., Bergmann, D., Rodriguez, J. M., Strahan, S., Wang, M., and Feng, Y.: Uncertainties in global aerosol simulations: Assessment using three meteorological data sets, J. Geophys. Res., 112, D11212, doi:10.1029/2006JD008216, 2007.

Logan, J. A.: An analysis of ozonesonde data for the troposphere: Recommendations for testing 3-D models, and development of a gridded climatology for tropospheric ozone, J. Geophys. Res., 104, 16115-16149, 1999.

Masarik, J. and Beer, J.: Simulation of particle fluxes and cosmogenic nuclide production in the Earth's atmosphere, J. Geophys. Res., 104, 12099-12111, 1999. 
Masarik, J. and Reedy, R. C.: Terrestrialcosmogenic-nuclide production systematic calculated from numerical simulations, Earth Planet. Sc. Lett. 136, 381-395, 1995.

McLinden, C. A., Olsen, S. C., Hannegan, B., Wild, O., and Prather, M. J.: Stratospheric ozone in 3-D models: A simple chemistry and the cross-tropopause flux, J. Geophys. Res., 105, 1465314665, 2000.

Miller, R. L. and Kahn, J. S.: Statistical analysis in the geological sciences, John Wiley and Sons, New York, USA, 204-210, 1962.

Murphy, D. M. and Fahey, D. W.: An estimate of the flux of stratospheric reactive nitrogen and ozone into the troposphere, J. Geophys. Res., 99, 5325-5332, 1994.

O'Brien, K., De La Zerda Lerner, A., Shea, M. A., and Smart, D. F.: The production of cosmogenic isotopes in the Earth's atmosphere and their inventories, in: The Sun in Time, Univ. of Ariz. Press, Tucson, USA, 317-342, 1991.

Olsen, M. A., Schoeberl, M. R., and Douglass, A. R.: Stratospheretroposphere exchange of mass and ozone, J. Geophys. Res., 109, D24114, doi:10.1029/2004JD005186, 2004.

Prospero, J. M., Schmitt, R., Curvas, E., Savoie, D. L., Graustein, W. C., Turekian, K. K., Volz-Thomas, A., Diaz, A., Oltmans, S. J., and Levy II, H.: Temporal variability of summer-time ozone and aerosols in the free troposphere over the eastern North Atlantic, Geophys. Res. Lett., 22, 2925-2928, 1995.

Raisbeck, G. M., Yiou, F., Fruneau, M., Loiseaux, J. M., Lieuvin, M., and Ravel, J. C.: Cosmogenic Be-10/Be-7 as a probe for atmospheric transport processes, Geophys. Res. Lett., 8, 10151018, 1981.

Rehfeld, S. and Heimann, M.: Three dimensional atmospheric transport simulation of the radioactive tracers ${ }^{210} \mathrm{~Pb},{ }^{7} \mathrm{Be},{ }^{10} \mathrm{Be}$, and ${ }^{90} \mathrm{Sr}$, J. Gephys. Res., 100, 26141-26161, 1995.

Riese, M., Ploeger, F., Rap, A., Vogel, B., Konopka, P., Dameris, M., and Forster, P.: Impact of uncertainties in atmospheric mixing on simulated UTLS composition and related radiative effects, J. Geophys. Res., 117, D16305, doi:10.1029/2012JD017751, 2012.

Rind, D. and Lerner, J.: Use of on-line tracers as a diagnostic tool in general circulation model development: 1 . Horizontal and vertical transport in the troposphere, J. Geophy. Res., 101, 1266712683, doi:10.1029/96JD00551, 1996.

Rind, D., Lerner, J., Jonas, J., and McLinden, C.: Effects of resolution and model physics on tracer transports in the NASA Goddard Institute for Space Studies general circulation models, J. Geophys. Res., 112, D09315, doi:10.1029/2006JD007476, 2007.

Rotman, D. A., Tannahill, J. R., Kinnison, D. E., Connell, P. S., Bergmann, D., Proctor, D., Rodriguez, J. M., Lin, S. J., Rood, R. B., Prather, M. J., Rasch, P. J., Considine, D. B., Ramaroson, R., and Kawa, S. R.: Global Modeling Initiative assessment model: Model description, integration, and testing of the transport shell, J. Geophys. Res., 106, 1669-1691, 2001.

Sanak, J., Lambert, G., and Ardouin, B.: Measurements of stratosphere-troposphere exchange in Antarctica by using shortlived cosmonuclides, Tellus B, 37, 109-115, 1985.

Schoeberl, M. R.: Extratropical stratosphere-troposphere mass exchange, J. Geophys. Res., 109, D13303, doi:10.1029/2004JD004525, 2004.

Schoeberl, M. R., Douglass, A. R., Zhu, Z., and Pawson, S.: A comparison of the lower stratospheric age spectra derived from a general circulation model and two data assimilation systems, J. Geophys. Res., 108, 4113, doi:10.1029/2002JD002652, 2003.
Shindell, D. T., Faluvegi, G., and Bell, N.: Preindustrial-to-presentday radiative forcing by tropospheric ozone from improved simulations with the GISS chemistry-climate GCM, Atmos. Chem. Phys., 3, 1675-1702, doi:10.5194/acp-3-1675-2003, 2003.

Škerlak, B., Sprenger, M., and Wernli, H.: A global climatology of stratosphere-troposphere exchange using the ERA-Interim data set from 1979 to 2011, Atmos. Chem. Phys., 14, 913-937, doi:10.5194/acp-14-913-2014, 2014.

Stajner, I., Wargan, K., Pawson, S., Hayashi, H., Chang, L.-P., Hudman, R. C., Froidevaux, L., Livesey, N., Levelt, P. F., Thompson, A. M., Tarasick, D. W., Stubi, R., Andersen, S. B., Yela, M., Konig-Langlo, G., Schmidlin, F. J., and Witte, J. C.: Assimilated ozone from EOS-Aura: Evaluation of the tropopause region and tropospheric columns, J. Geophys. Res., 113, D16S32, doi:10.1029/2007JD008863, 2008.

Stevenson, D. S., Dentener, F. J., Schultz, M. G., Ellingsen, K., van Noije, T. P. C., Wild, O., Zeng, G., Amann, M., Atherton, C. S., Bell, N., Bergmann, D. J., Bey, I., Butler, T., Cofala, J., Collins, W. J., Derwent, R. G., Doherty, R. M., Drevet, J., Eskes, H. J., Fiore, A. M., Gauss, M., Hauglustaine, D. A., Horowitz, L. W., Isaksen, I. S. A., Krol, M. C., Lamarque, J.-F., Lawrence, M. G., Montanaro, V., Müller, J.-F., Pitari, G., Prather, M. J., Pyle, J. A., Rast, S., Rodriguez, J. M., Sanderson, M. G., Savage, N. H., Shindell, D. T., Strahan, S. E., Sudo, K., and Szopa, S.: Multimodel ensemble simulations of present-day and near-future tropospheric ozone, J. Geophys. Res., 111, D08301, doi:10.1029/2005JD006338, 2006.

Stohl, A., Bonasoni, P., Cristofanelli, P., Collins, W., Feichter, J., Frank, A., Forster, C., Gerasopoulos, E., Gäggeler, H., James, P., Kentarchos, T., Kromp-Kolb, H., Krüger, B., Land, C., Meloen, J., Papayannis, A., Priller, A., Seibert, P., Sprenger, M., Roelofs, G. J., Scheel, H. E., Schnabel, C., Siegmund, P., Tobler, L., Trickl, T., Wernli, H., Wirth, V., Zanis, P., and Zerefos, C.: Stratosphere-troposphere exchange: A review, and what we have learnt from STACCATO, J. Geophys. Res., 108, 8516, doi:10.1029/2002JD002490, 2003.

Strahan, S. E. and Douglass, A. R.: Evaluating the credibility of transport processes in simulations of ozone recovery using the Global Modeling Initiative three-dimensional model, J. Geophys. Res., 109, D05110, doi:10.1029/2003JD004238, 2004.

Strahan, S. E., Duncan, B. N., and Hoor, P.: Observationally derived transport diagnostics for the lowermost stratosphere and their application to the GMI chemistry and transport model, Atmos. Chem. Phys., 7, 2435-2445, doi:10.5194/acp-7-2435-2007, 2007.

Strahan, S. E., Schoeberl, M. R., and Steenrod, S. D.: The impact of tropical recirculation on polar composition, Atmos. Chem. Phys., 9, 2471-2480, doi:10.5194/acp-9-2471-2009, 2009.

Terao, Y., Logan, J. A., Douglass, A. R., and Stolarski, R. S.: Contribution of stratospheric ozone to the interannual variability of tropospheric ozone in the northern extratropics, J. Geophys. Res., 113, D18309, doi:10.1029/2008JD009854, 2008.

Thompson, A. M., Witte, J. C., McPeters, R. D., Oltmans, S. J., Schmidlin, F. J., Logan, J. A., Fujiwara, M., Kirchhoff, V. W. J. H., Posny, F., Coetzee, G. J. R., Hoegger, B., Kawakami, S., Ogawa, T., Johnson, B. J., Vömel, H., and Labow, G.: Southern Hemisphere Additional Ozonesondes (SHADOZ) 1998-2000 tropical ozone climatology - 1. Comparison with Total Ozone Mapping Spectrometer (TOMS) and groundbased measure- 
ments, J. Geophys. Res., 108, 8238, doi:10.1029/2001JD000967, 2003.

Tsutsumi, Y., Igarashi, Y., Zaizen, Y., and Makino, Y.: Case studies of tropospheric ozone events observed at the summit of Mount Fuju, J. Geophys. Res., 103, 16935-16951, 1998.

Usoskin, I. G. and Kovaltsov, G. A.: Production of cosmogenic ${ }^{7} \mathrm{Be}$ isotope in the atmosphere: Full 3-D modeling, J. Geophys. Res., 113, D12107, doi:10.1029/2007JD009725, 2008.

Viezee, W. and Singh, H. B.: The distribution of beryllium-7 in the troposphere: Implications on stratosphere/tropospheric air exchange, Geophys. Res. Lett., 7, 805-808, 1980.

Yang, Q., Cunnold, D. M., Choi, Y., Wang, Y., Nam, J., Wang, H.J., Froidevaux, L., Thompson, A. M., and Bhartia, P. K.: A study of tropospheric ozone column enhancements over North America using satellite data and a global chemical transport model, J. Geophys. Res., 115, D08302, doi:10.1029/2009JD012616, 2010.

Young, P. J., Archibald, A. T., Bowman, K. W., Lamarque, J.-F., Naik, V., Stevenson, D. S., Tilmes, S., Voulgarakis, A., Wild, O., Bergmann, D., Cameron-Smith, P., Cionni, I., Collins, W. J., Dalsøren, S. B., Doherty, R. M., Eyring, V., Faluvegi, G., Horowitz, L. W., Josse, B., Lee, Y. H., MacKenzie, I. A., Nagashima, T., Plummer, D. A., Righi, M., Rumbold, S. T., Skeie, R. B., Shindell, D. T., Strode, S. A., Sudo, K., Szopa, S., and Zeng, G.: Preindustrial to end 21st century projections of tropospheric ozone from the Atmospheric Chemistry and Climate Model Intercomparison Project (ACCMIP), Atmos. Chem. Phys., 13, 2063 2090, doi:10.5194/acp-13-2063-2013, 2013.
Zanis, P., Gerasopoulos, E., Priller, A., Schnabel, C., Stohl, A., Zerefos, C., Gäggeler, H. W., Tobler, L., Kubik, P. W., Kanter, H. J., Scheel, H. E., Luterbacher, J., and Berger, M.: An estimate of the impact of stratosphere-to-troposphere transport (STT) on the lower free tropospheric ozone over the Alps using ${ }^{10} \mathrm{Be}$ and ${ }^{7} \mathrm{Be}$ measurements, J. Geophys. Res., 108, 8520, doi:10.1029/2002JD002604, 2003.

Ziemke, J. R., Chandra, S., Duncan, B. N., Froidevaux, L., Bhartia, P. K., Levelt, P. F., and Waters, J. W.: Tropospheric ozone determined from Aura OMI and MLS: Evaluation of measurements and comparison with the Global Modeling Initiative's Chemical Transport Model, J. Geophys. Res., 111, D19303, doi:10.1029/2006JD007089, 2006. 